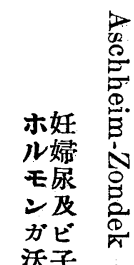

沃子，

度宫 所

陳患 請

代者 妊

=中

及, 應

ボ所

影謂ル

響下 モ

=垂ノ

就體 、

下葉 㭃

至若

中 万

又

白

白

$=$

娃

婦

尿

7

注

射

九時

二 時

言亥

動

物

>

卵

雀

$=$

對

テ
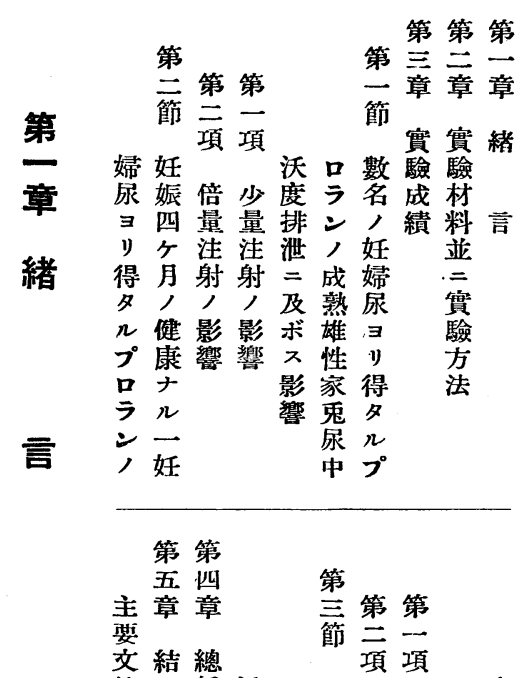

交 結 總

括沃品学成 亚度 $三$ 宮倍少及熟 論二排ン癌量量ボ雄 考泄, 患注注 按=成者射射影家 及熟沓, , 響鬼 ボ雄 $\exists$ 影影

ス性り響響

影家得

皦 鬼タ

尿儿

中 $7^{\circ}$
次

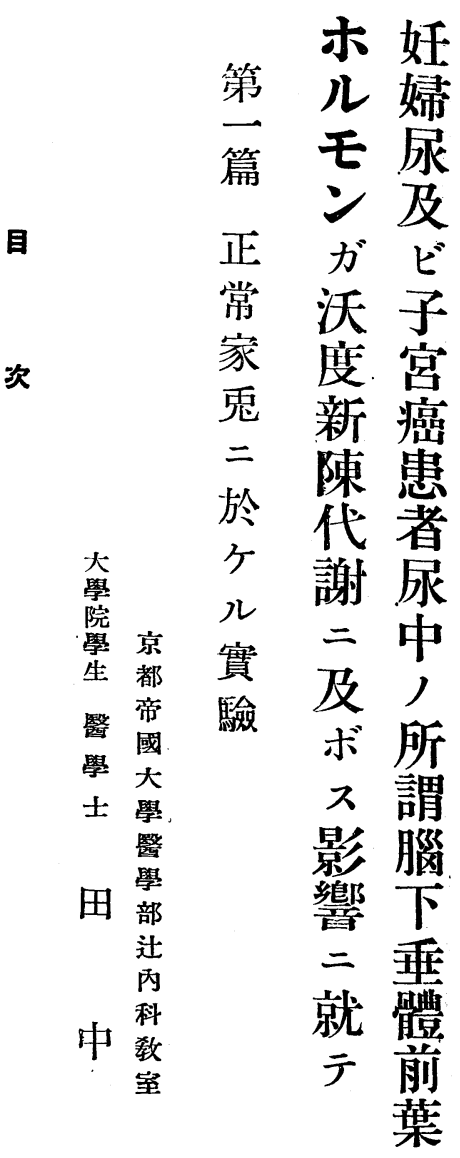

郁
篇 モ尿

正 ガ ビ

常 沃子 度 宮 新 癌

陳 患 代者 謝 尿

二中 及

ボ所

ス謂

影 腦

響下

二重

就 體

テ 前

葉 


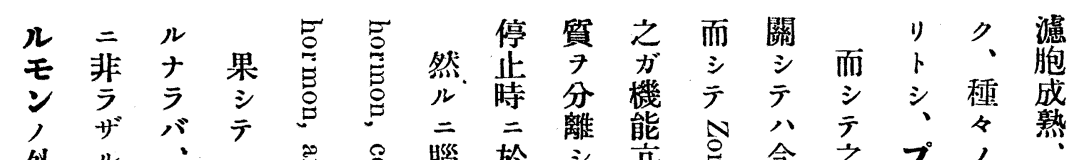

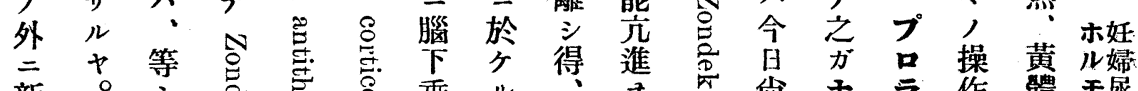

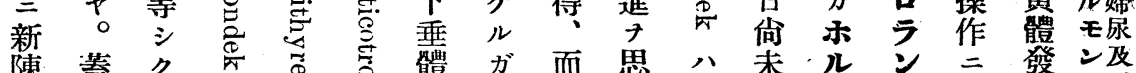
花 溘 前

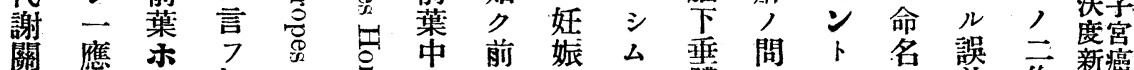
藇公公 如

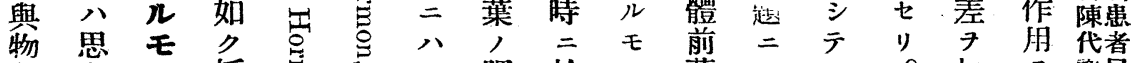

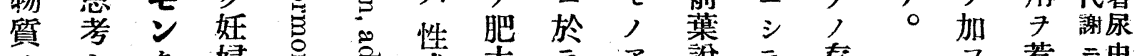

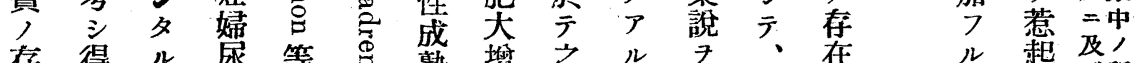

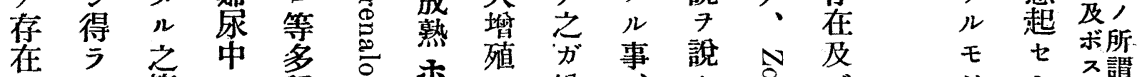

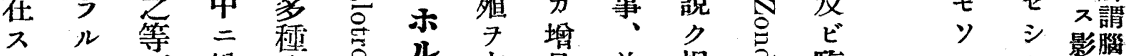

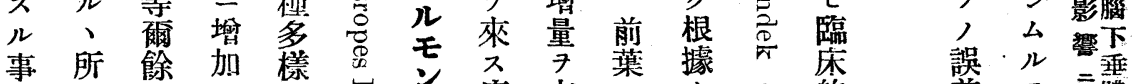

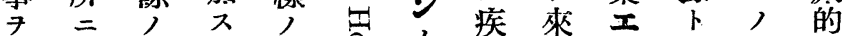

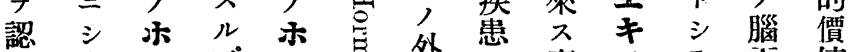

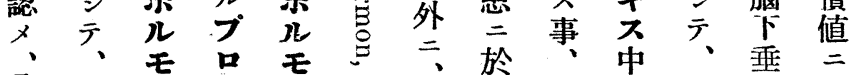

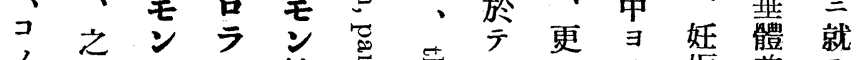

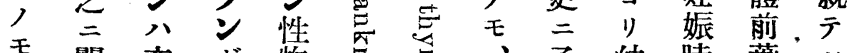
モ 關 亦 ガ 物

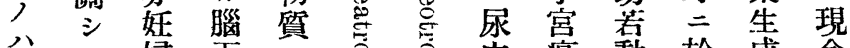
人 $心$ 婦下, 妾妾中癌動於成含

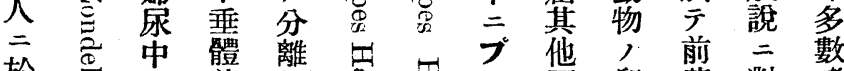

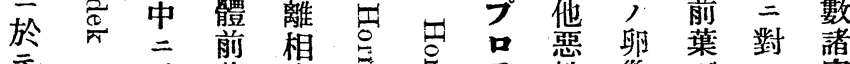

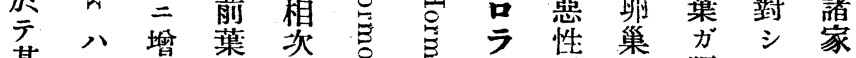
基 其加

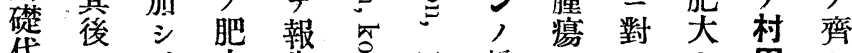

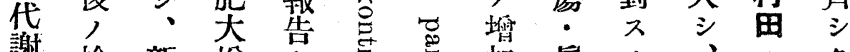

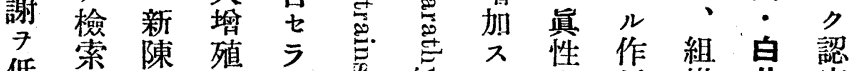

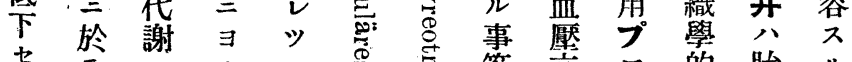

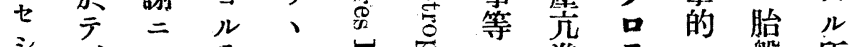

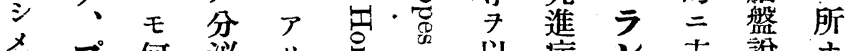

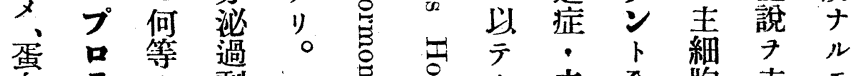

息亏尔剩

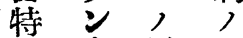

種 中 影タ 動 二 響 $メ$ 力 性 7 ナ 作 成 與 リ 用嘸 7 卜 去㙓全胞表 努 相 增 其 䚺モル體 率 こ 就前

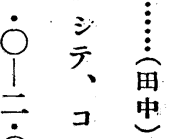
\% 丹 應 出夕 デル ズヤ

上 弤 云 娠 ○ 極

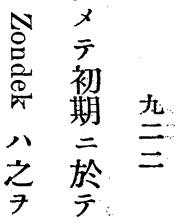
一 $₹$ 種 明 力

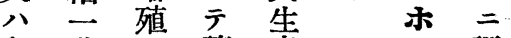
卵致 7 讓 肴認 巢

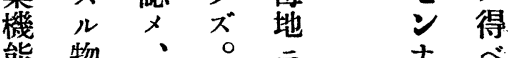



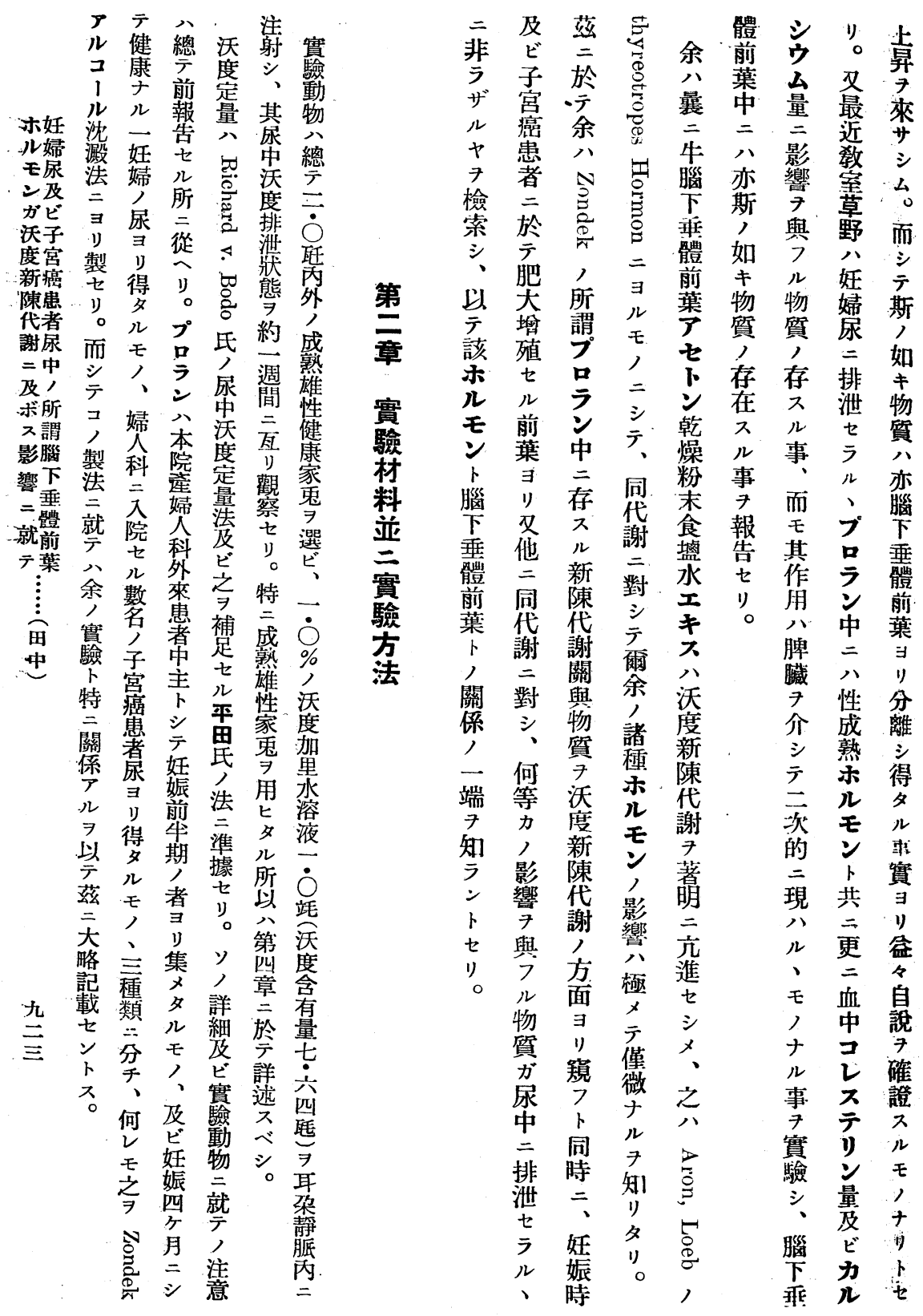


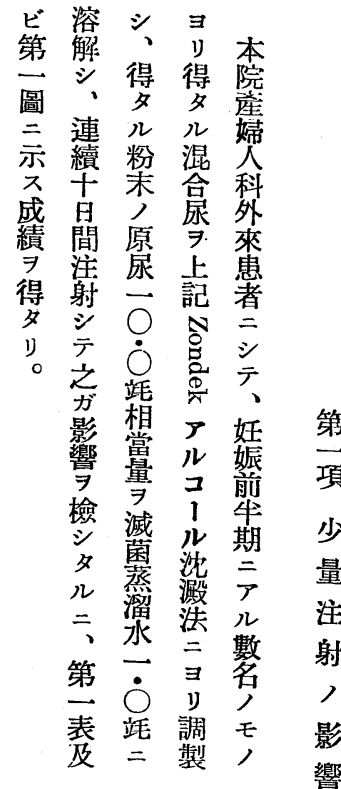

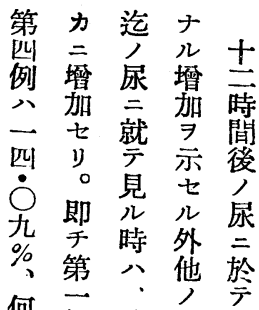

何例第 三六

增 六例第

架爷稍 方 倣

第 \% 減 著 於

例第少 變 宁

五例儿外立六

六三柋三立

$\% \bigcirc$ 何 市 \%

減五 2 四了

少虫 モ 時 蓄

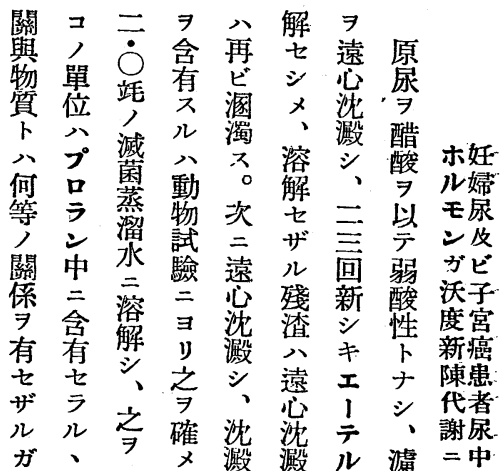

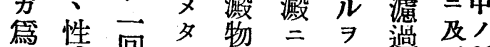

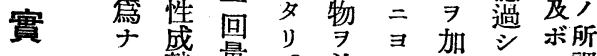

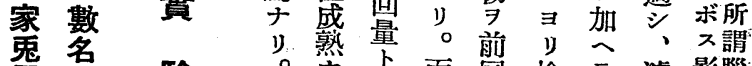
䐂名驗

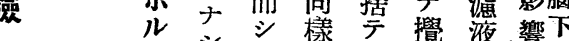

ルシ シ 樣テ攪倠、響下

モジテエ、挷

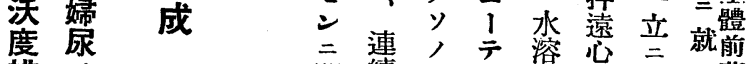

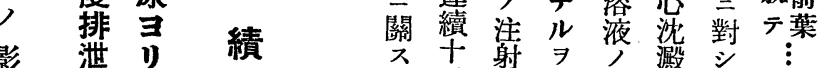

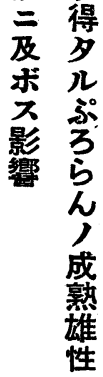

ル 昆量以ミ势九

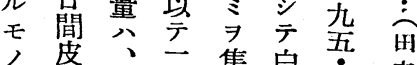

二年原集自它虫

：二尿回、， \%

テ 注 一洗 コ沈

、射 ○滥, 澱ル

余七宁精 夜物

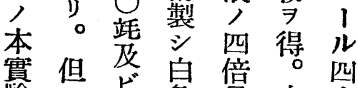

驗 シ E゙色量 次立

於, 粉九之 加

檢該站年蒸振

索木相ナ 0 溜鹳

七ル當

レ モ

ス八上クコ嵒後西

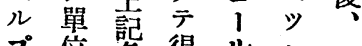

プ位各得ル、一

口量 粉夕 3 振 書

ラ 采 加盪夜

中定 $\rightarrow$ 粉

新 で

陳。靖品時水次

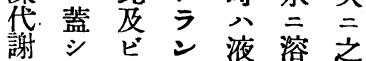




\begin{tabular}{|c|c|c|c|c|c|c|c|}
\hline & \multicolumn{2}{|c|}{$\infty$} & \multicolumn{2}{|c|}{ No } & \multicolumn{2}{|c|}{$\omega$} & \multirow{2}{*}{ 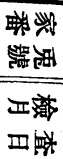 } \\
\hline & $\begin{array}{l}\stackrel{y}{y} \\
\Rightarrow\end{array}$ & $\stackrel{N}{=}$ & $\begin{array}{l}\triangleq \\
\triangleq\end{array}$ & $\stackrel{N}{=}$ & $\begin{array}{l}\vec{y} \\
\Xi\end{array}$ & $\stackrel{\sqrt[N]{-}}{=}$ & \\
\hline 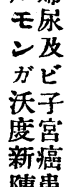 & 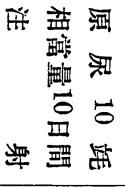 & 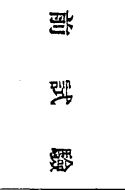 & 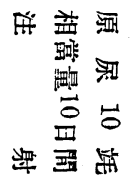 & 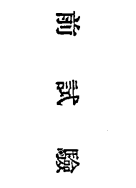 & 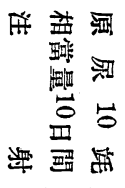 & 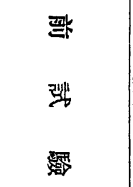 & \\
\hline $\begin{array}{l}\text { 代者 } \\
=\text { 謝 }\end{array}$ & $\ddot{\mathscr{o}}$ & 웅 & $\stackrel{\oplus}{\mathscr{0}}$ & $\stackrel{0}{0}$ & $\stackrel{N}{\stackrel{N}{O}}$ & $\frac{10}{8}$ & 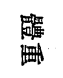 \\
\hline 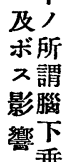 & 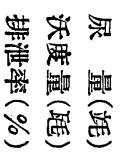 & 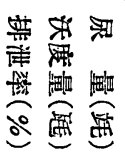 & 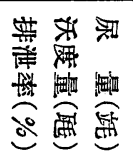 & 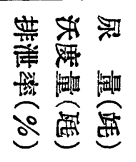 & 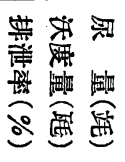 & 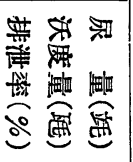 & \\
\hline $\begin{array}{l}\text { 體 } \\
\text { 就前 } \\
\text { テ葉 }\end{array}$ & 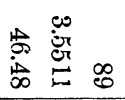 & 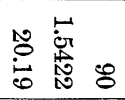 & 峁 & 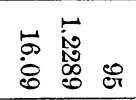 & 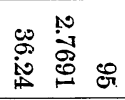 & 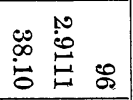 & 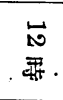 \\
\hline$\stackrel{\vdots}{\stackrel{\text { 男 }}{\text { 中 }}}$ & 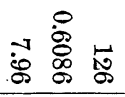 & 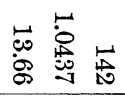 & 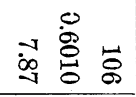 & 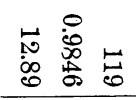 & ن & 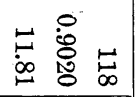 & 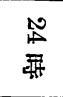 \\
\hline 3 & 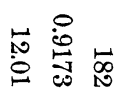 & 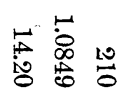 & 俤总 & 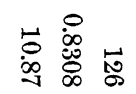 & 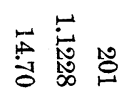 & 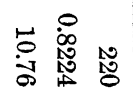 & $\begin{array}{l}\infty \\
\infty \\
\text { 费 }\end{array}$ \\
\hline & 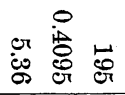 & 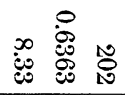 & 范容 N & 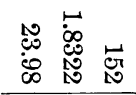 & 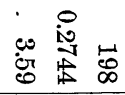 & 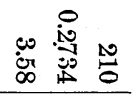 & $\begin{array}{l}N \\
\text { \# }\end{array}$ \\
\hline & 유용 & 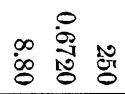 & 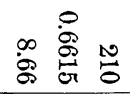 & 兑 & 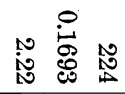 & 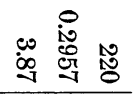 & $\begin{array}{l}\mathscr{8} \\
\text { 永 }\end{array}$ \\
\hline & ○ & 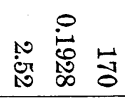 & 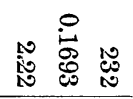 & 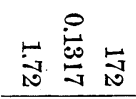 & 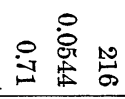 & 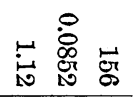 & 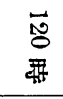 \\
\hline $\begin{array}{l}\text { 旮 } \\
\text { 五 }\end{array}$ & 1 & 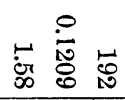 & $\begin{array}{l}\stackrel{0}{1} \\
\dot{10} \\
0\end{array}$ & 宛点品 & 1 & 1 & 突 \\
\hline & 1 & 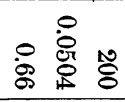 & @ & 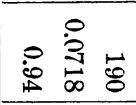 & -1 & 1 & $\begin{array}{c}\stackrel{8}{\infty} \\
5\end{array}$ \\
\hline & 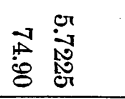 & 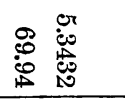 & 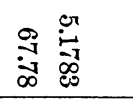 & 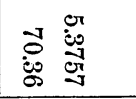 & 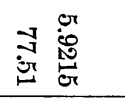 & 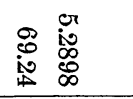 & 望 \\
\hline & & & & & & & $\widehat{x}^{2}$ \\
\hline
\end{tabular}


第一圖 第一表, 第三號家鬼

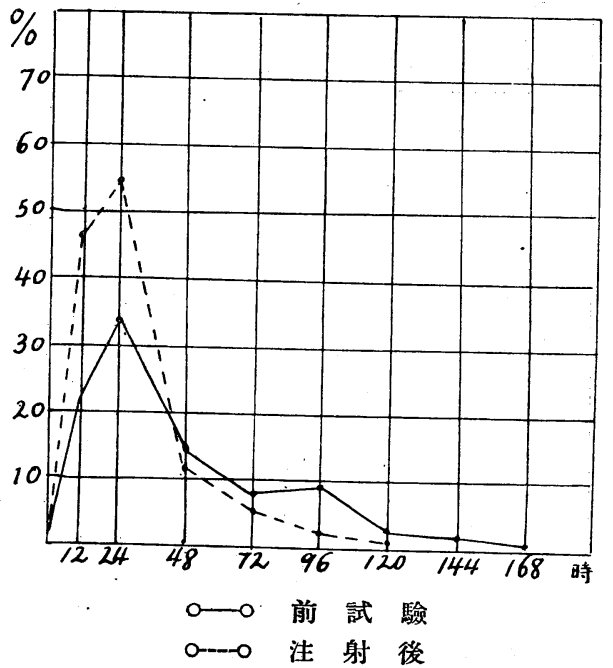

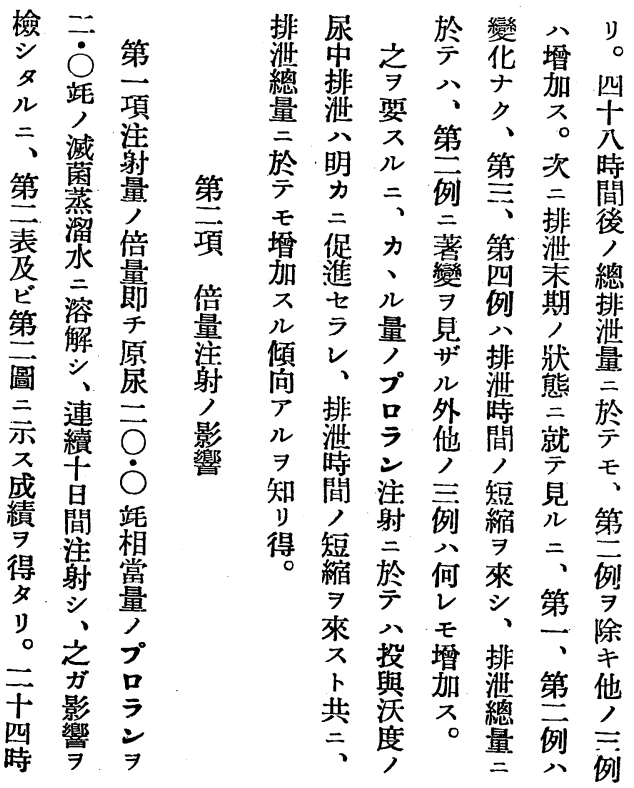

\begin{tabular}{|c|c|c|}
\hline \multicolumn{2}{|c|}{ 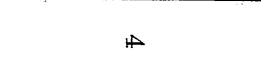 } & 职 \\
\hline$\stackrel{\Xi}{\exists}$ & $\stackrel{N}{=}$ & $\begin{array}{l}\text { 西高 } \\
\text { 四策 }\end{array}$ \\
\hline 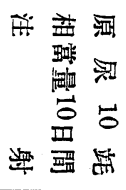 & 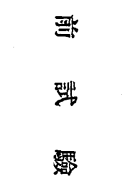 & \\
\hline : & $\underset{0}{\stackrel{1}{0}}$ & 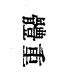 \\
\hline 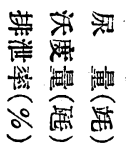 & 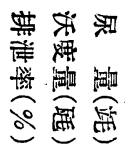 & $\because$ \\
\hline 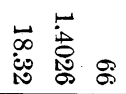 & 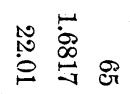 & $\begin{array}{l}\vec{N} \\
\text { 霖 }\end{array}$ \\
\hline 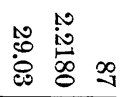 & 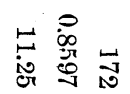 & $\begin{array}{l}\stackrel{N}{1} \\
\text { 帅 }\end{array}$ \\
\hline 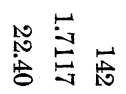 & 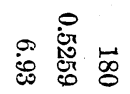 & $\stackrel{\infty}{\infty}$ \\
\hline 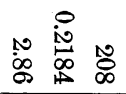 & 串 & $\begin{array}{l}\text { Nै } \\
\text { 丞 }\end{array}$ \\
\hline 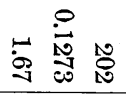 & 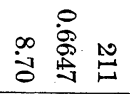 & $\underset{8}{\mathscr{F}}$ \\
\hline 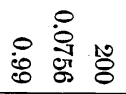 & 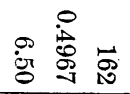 & $\begin{array}{l}\overrightarrow{5} \\
\text { 昰 }\end{array}$ \\
\hline 1 & 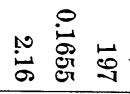 & $\begin{array}{l}\text { 点 } \\
\text { 霖 }\end{array}$ \\
\hline 1 & $\begin{array}{l}\circ \\
\text { 용 } \\
\dot{\infty} \\
0\end{array}$ & $\begin{array}{l}\infty \\
\infty \\
\infty \\
\text { a }\end{array}$ \\
\hline 럽 & 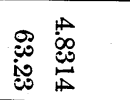 & 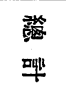 \\
\hline & & 仓゚ \\
\hline
\end{tabular}




\begin{tabular}{|c|c|c|c|c|c|c|c|c|}
\hline & \multirow{2}{*}{$\frac{\Delta}{\overrightarrow{0}}$} & \multicolumn{2}{|r|}{ مت } & \multicolumn{2}{|c|}{ N } & \multicolumn{2}{|c|}{$\varpi$} & \multirow{2}{*}{ 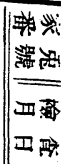 } \\
\hline & & $\stackrel{e r}{a}$ & $\stackrel{b}{a}$ & $\stackrel{\text { er }}{\text { a }}$ & $\grave{0}$ & $\stackrel{\text { or }}{i}$ & $\stackrel{0}{\circ}$ & \\
\hline 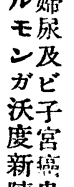 & 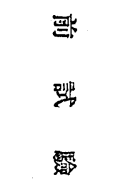 & 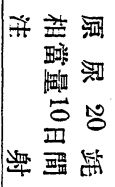 & 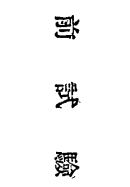 & 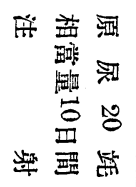 & 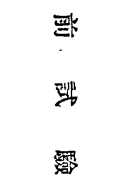 & 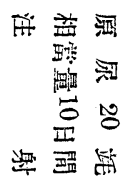 & 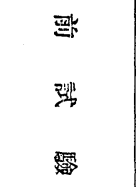 & \\
\hline $\begin{array}{l}\text { 代者 } \\
=\text { 謝原 } \\
=\text { 中 }\end{array}$ & $\begin{array}{l}0 \\
0 \\
0\end{array}$ & 䇛 & $\begin{array}{l}\stackrel{w}{\infty} \\
0 \\
0\end{array}$ & : & $\begin{array}{l}\text { No } \\
\text { - } \\
0\end{array}$ & 苑 & $\begin{array}{l}\text { 옹 } \\
\text { \% }\end{array}$ & 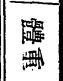 \\
\hline 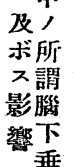 & 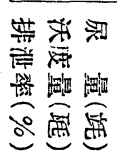 & 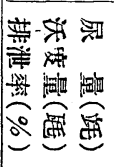 & 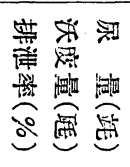 & 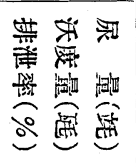 & 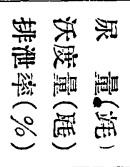 & 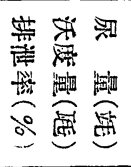 & 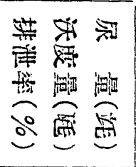 & \\
\hline 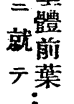 & $\begin{array}{ll} & \text { iv } \\
\text { er } & 0 \\
0 & 0\end{array}$ & 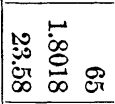 & 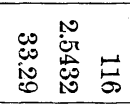 & 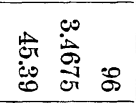 & 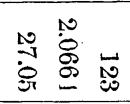 & 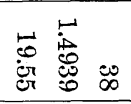 & 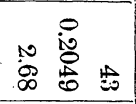 & $\begin{array}{l}\overrightarrow{0} \\
\nexists \mathbb{\#}\end{array}$ \\
\hline$\stackrel{\grave{\vdots}}{\dot{⿴ 囗 十}}$ & 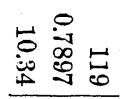 & 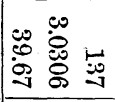 & 잉 & 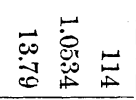 & 完葱 & 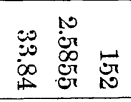 & 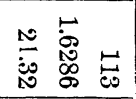 & 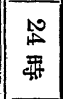 \\
\hline & 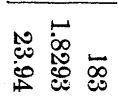 & 总 & 苛 总 & 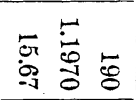 & 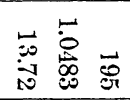 & 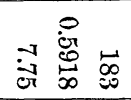 & 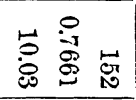 & 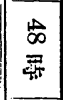 \\
\hline & or & 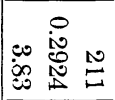 & 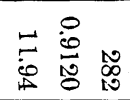 & 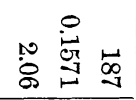 & 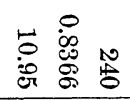 & 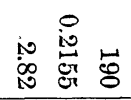 & 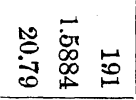 & 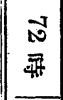 \\
\hline & 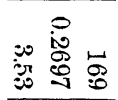 & 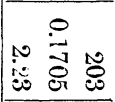 & 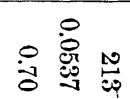 & 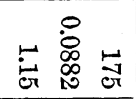 & 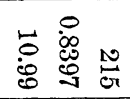 & 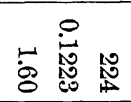 & 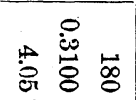 & $\mathscr{8}$ \\
\hline & 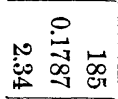 & $\begin{array}{ccc} & 0 \\
0 & 0 & \\
0 & \infty & \\
0 & \infty & \infty \\
0 & 1 & 1\end{array}$ & 1 & 잉 & 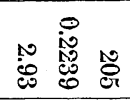 & 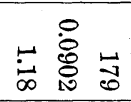 & 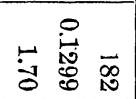 & $\begin{array}{l}\overrightarrow{8} \\
\text { 舞 }\end{array}$ \\
\hline$\frac{\text { 九 }}{\text { 七 }}$ & 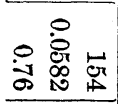 & 1 & 1 & 1 & 岕泀嵌 & 1 & 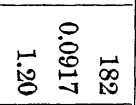 & 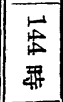 \\
\hline & 1 & 1 & 1 & 1 & ஜ & 1 & 1 & ; \\
\hline & 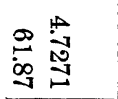 & 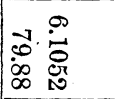 & 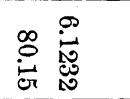 & 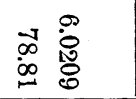 & 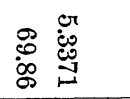 & 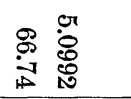 & 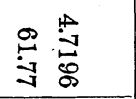 & 罂 \\
\hline & $\underset{\infty}{+}$ & & 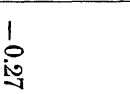 & & & & & o \\
\hline
\end{tabular}


第二圖 第二表，第二號家鬼

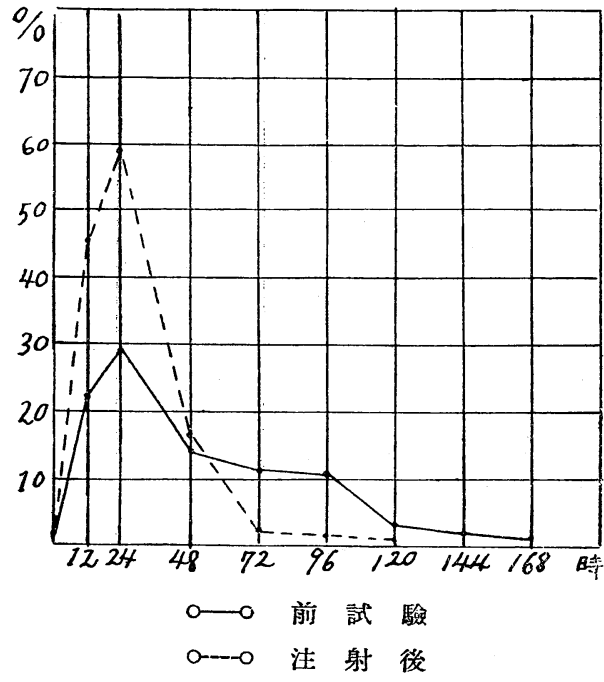

比䌊總四六\%儿間

三慢量 例 $\bigcirc$ 外迄

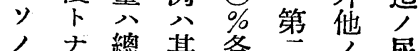

堆儿總其各家分尿

加外六泄增 分例就

率他增 時 加三八六

立 分加間

於四 $\Rightarrow \Rightarrow 0 \div$ 的

然例認短排六壬二

更著。縮渫 \% 蓄、

著 $=$ 第期第 增 五

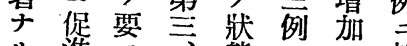

儿進不態公七於

$\exists$ 七ル第寻八刀方

見 ラ二、吾 見旮即九

前 例 稍 $=\%$ 第 六

溑 於 莚 第 第例 $\%$

, 排 辰第 例三文少

場泄。兰八九

合稍排

\begin{tabular}{|c|c|c|}
\hline \multicolumn{2}{|c|}{ or } & \multirow[b]{2}{*}{$\stackrel{\text { or }}{i}$} \\
\hline$\stackrel{\text { r }}{\equiv}$ & 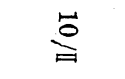 & \\
\hline 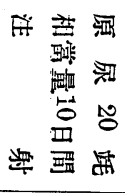 & 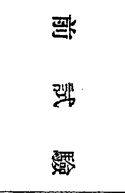 & 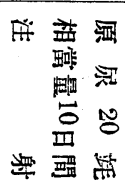 \\
\hline $\overrightarrow{0}$ & $\begin{array}{l}\stackrel{0}{10} \\
\stackrel{0}{0}\end{array}$ & $\overrightarrow{8}$ \\
\hline 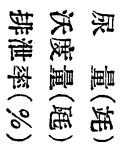 & 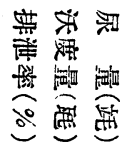 & 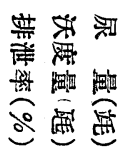 \\
\hline 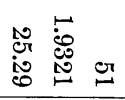 & 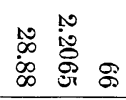 & 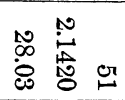 \\
\hline 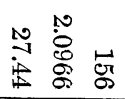 & 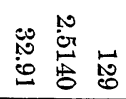 & 范宫若 \\
\hline 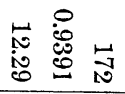 & 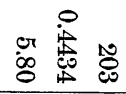 & 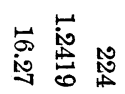 \\
\hline ثึ & 泀总 & 하용 \\
\hline 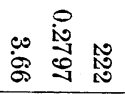 & 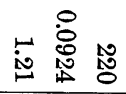 & 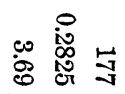 \\
\hline 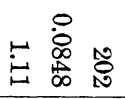 & $i$ & ○ \\
\hline 1 & 1 & 1 \\
\hline 1 & 1 & 1 \\
\hline ç & 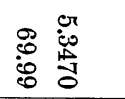 & 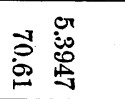 \\
\hline & & \\
\hline
\end{tabular}




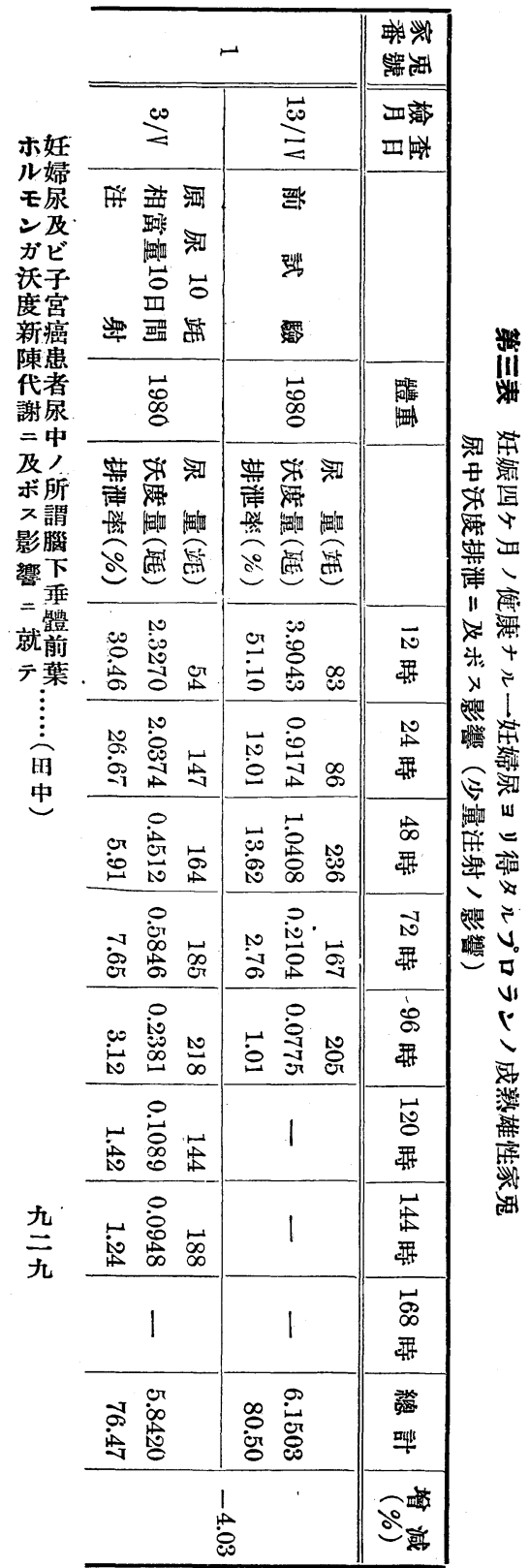

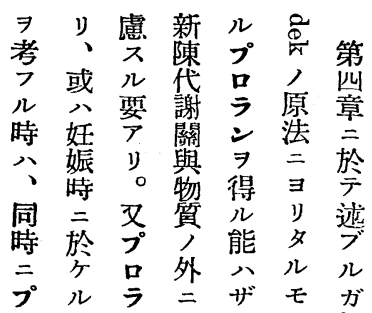

口種ざルノ如

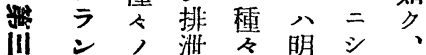

糔中合量, カテ上節

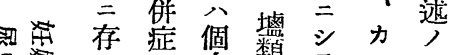

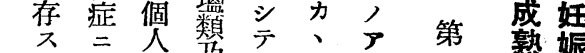

品 ル

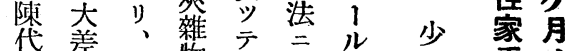

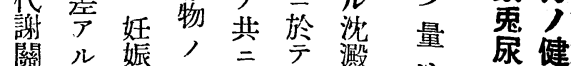

與 洔影介八法注 中康

筫总期響在純分射沃广

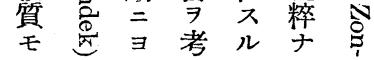

王 溜 先 製 症 获 個

) 屒

影泄姡

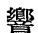

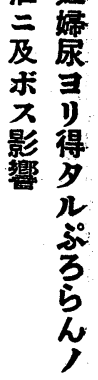

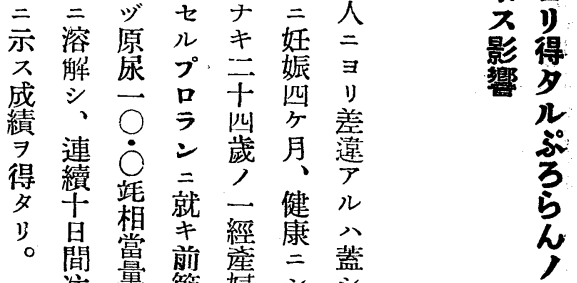

注量 節 嫦 シ シ

射 プ后ノテ 思

シ 、樣早 特考

之 シ赛光市得

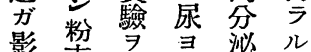

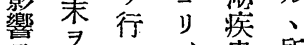

寻一 乞 前患所

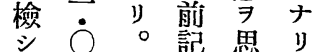

多踥同分。

ル隇 榚 ス サ

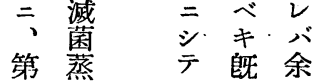




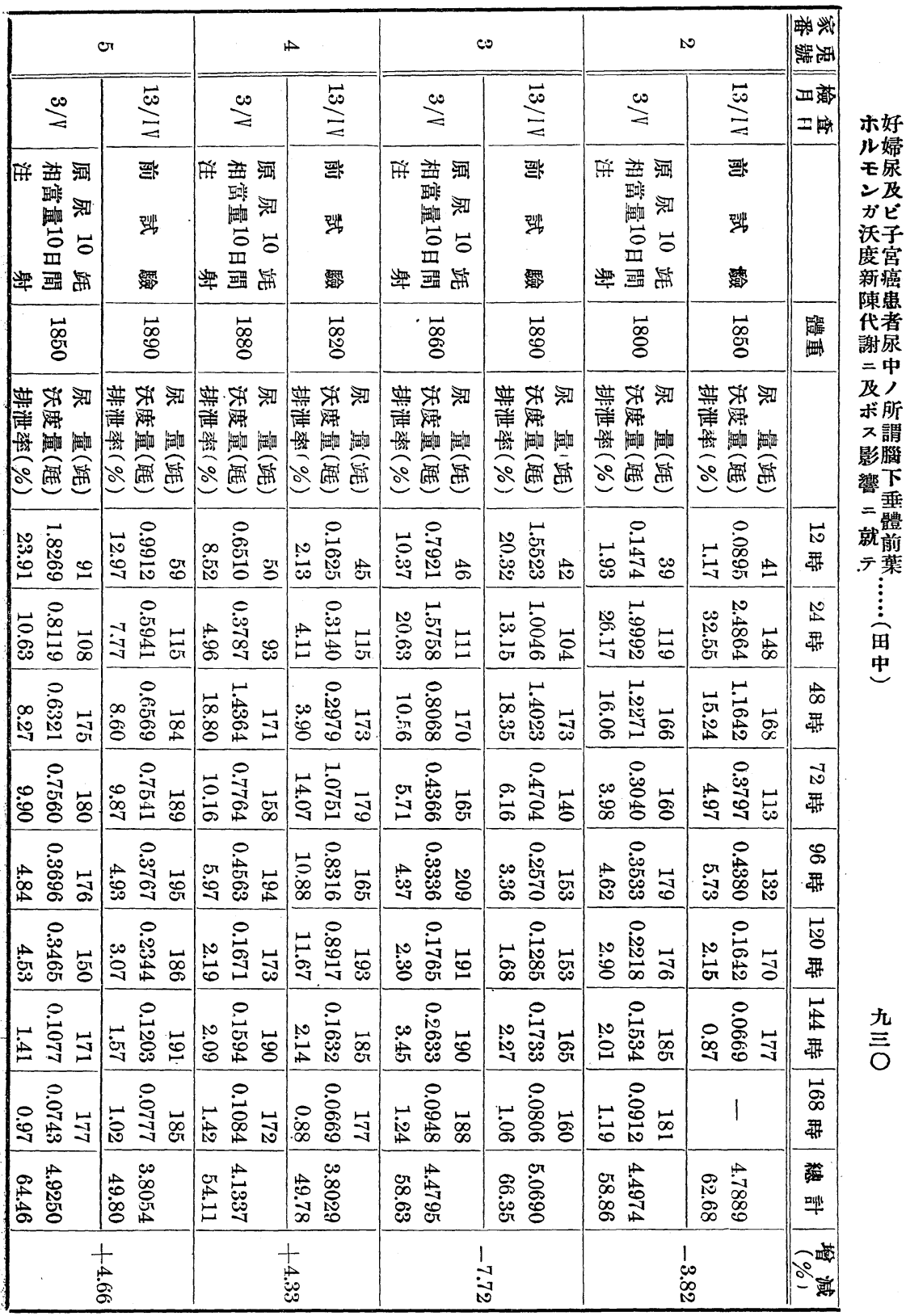



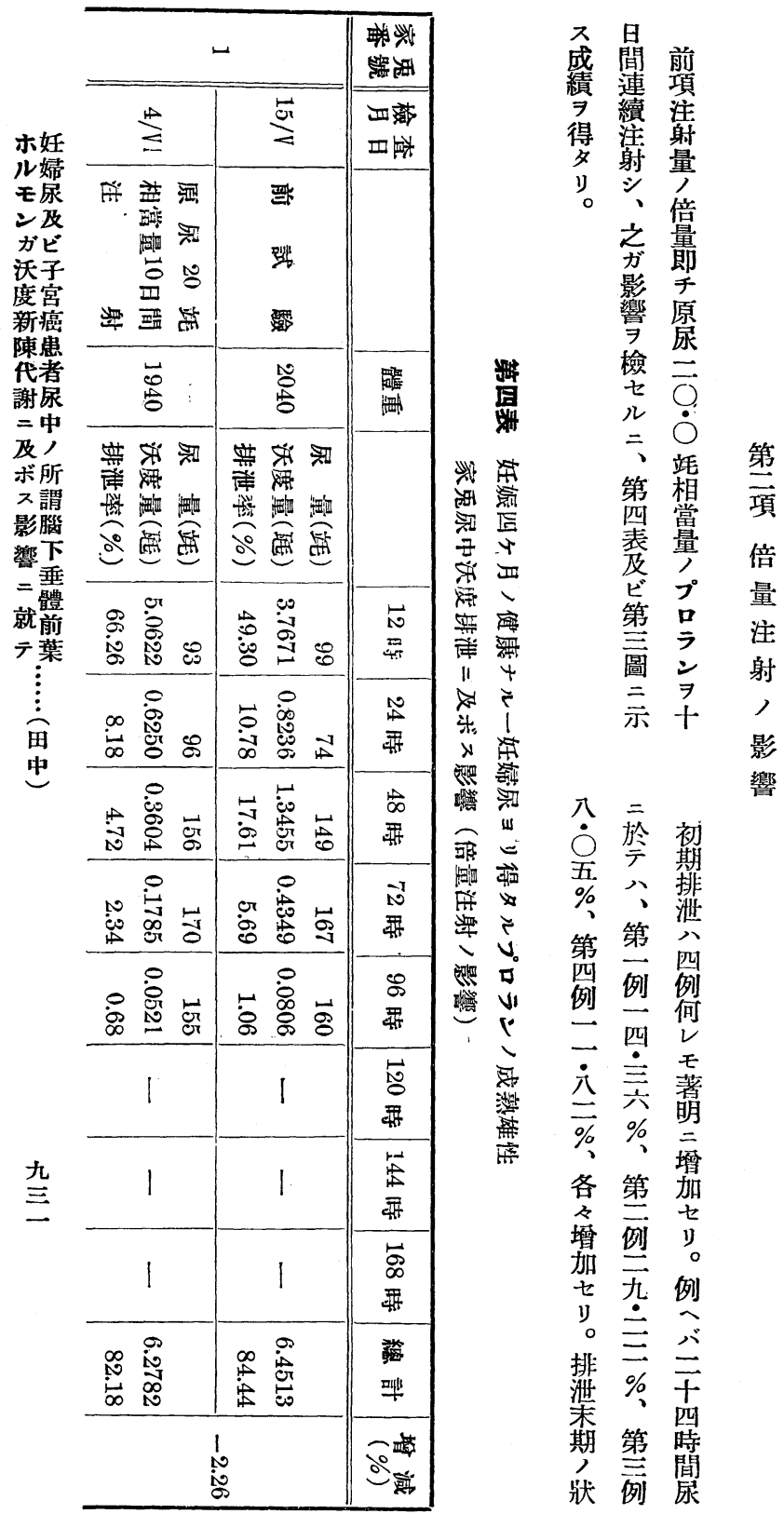

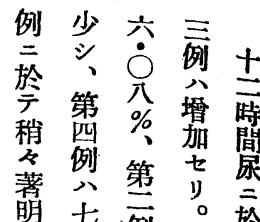
奛文例然答

瀷面吾然心

驾第京三第

示吾爷市第

外八裂

公三第間

堡言公曒第

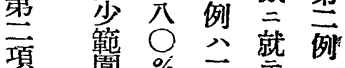

倍离篞完見著

却架七儿 明

於

增 即 何 第少

減第志例他

影

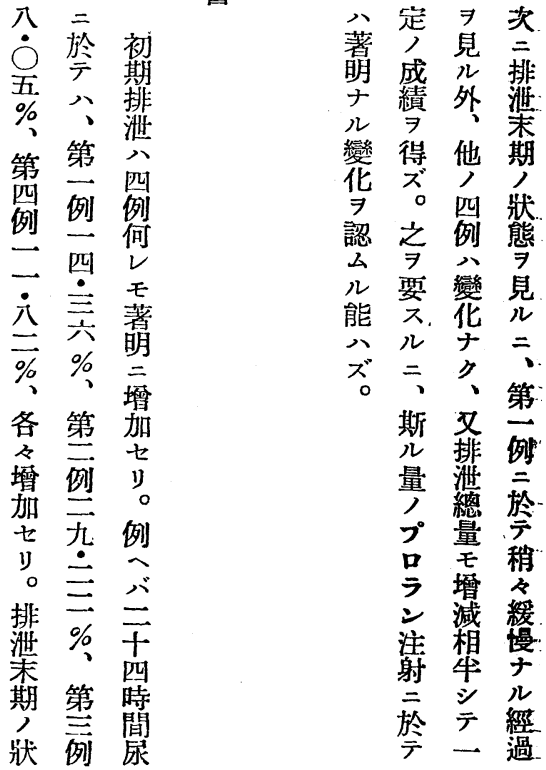




\begin{tabular}{|c|c|c|c|c|c|c|}
\hline \multicolumn{2}{|r|}{ ( } & \multicolumn{2}{|c|}{$\infty$} & \multicolumn{2}{|c|}{ ה } & \multirow{2}{*}{ 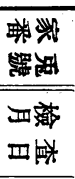 } \\
\hline 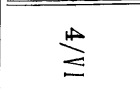 & s & $\stackrel{\stackrel{\Perp}{\Xi}}{\Xi}$ & $\frac{g r}{g}$ & $\cong$ & $\stackrel{g r}{g}$ & \\
\hline 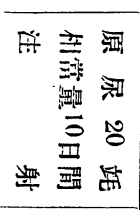 & 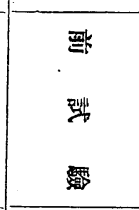 & 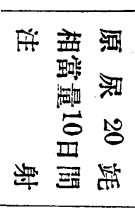 & 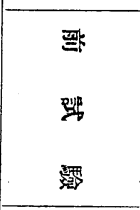 & 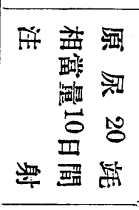 & 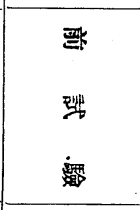 & \\
\hline 范 & : & $\begin{array}{l}\vec{\infty} \\
0 \\
0\end{array}$ & $\ddot{g}$ & 亜 & 器 & 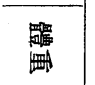 \\
\hline 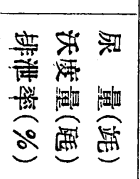 & 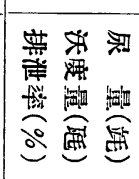 & 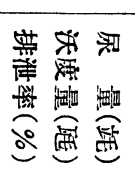 & 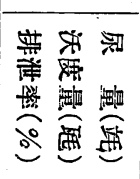 & 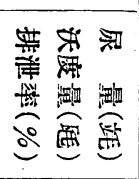 & 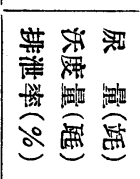 & \\
\hline 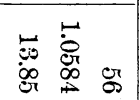 & 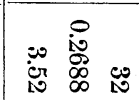 & D. & 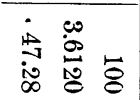 & 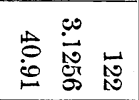 & 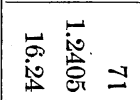 & 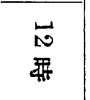 \\
\hline 要墕 & 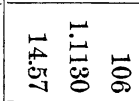 & 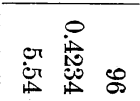 & 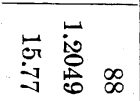 & 夢兽 & 总 & 贺 \\
\hline 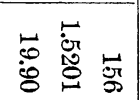 & 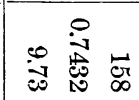 & 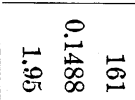 & 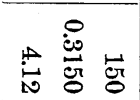 & 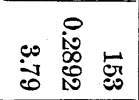 & 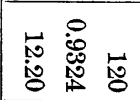 & 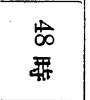 \\
\hline 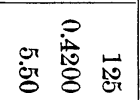 & 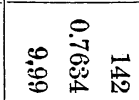 & 尊总 & 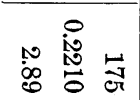 & 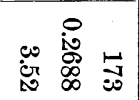 & 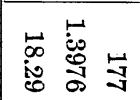 & 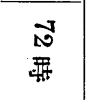 \\
\hline 总总 & 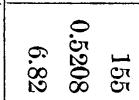 & I & 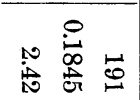 & 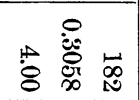 & 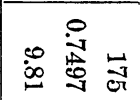 & $\begin{array}{l}8 \\
\$\end{array}$ \\
\hline 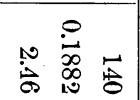 & 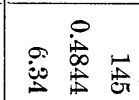 & 1 & 总总 & 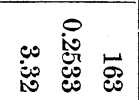 & 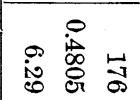 & 舜 \\
\hline 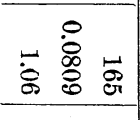 & 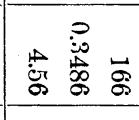 & 1 & 1 & 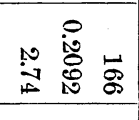 & 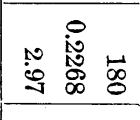 & 箇 \\
\hline 1 & : & 1 & 1 & 总总 & 章章 & 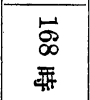 \\
\hline 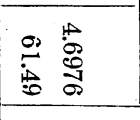 & 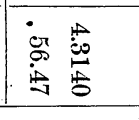 & 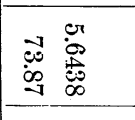 & 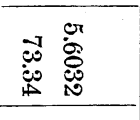 & 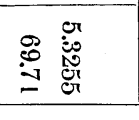 & 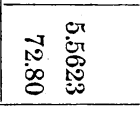 & \begin{tabular}{|l|} 
涪 \\
品 \\
\end{tabular} \\
\hline & $\stackrel{8}{2}$ & & 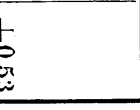 & & & 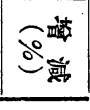 \\
\hline
\end{tabular}




\begin{tabular}{|c|c|c|c|}
\hline & \multicolumn{2}{|c|}{$\omega$} & \multirow{2}{*}{ 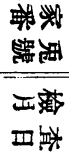 } \\
\hline & $\stackrel{\vec{\sigma}}{\triangleq}$ & 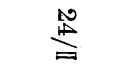 & \\
\hline $\begin{array}{l}\text { モ尿 } \\
\text { 范 } \\
\text { 沃 } \\
\text { 沃子 } \\
\text { 度宫 } \\
\text { 新癌 }\end{array}$ & 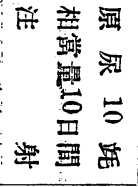 & 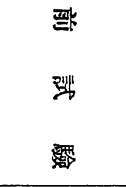 & \\
\hline $\begin{array}{l}\text { 代者 } \\
\text { 謝㫤 } \\
=\text { 中 }\end{array}$ & : & 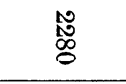 & 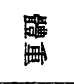 \\
\hline $\begin{array}{l}\text { 及促 } \\
\text { 苯所 } \\
\text { 謂 } \\
\text { 影腦 } \\
\text { 響下 }\end{array}$ & 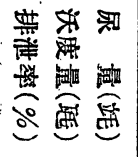 & 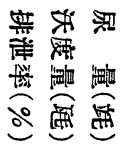 & \\
\hline $\begin{array}{l}\text { 就箱 } \\
\text { テ葥 }\end{array}$ & 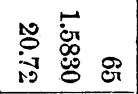 & 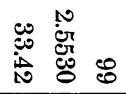 & N \\
\hline $\begin{array}{l}\text { 田 } \\
\text { 中 }\end{array}$ & 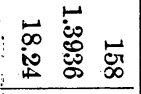 & 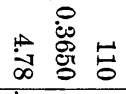 & $\begin{array}{l}\stackrel{N}{\perp} \\
\text { 承 }\end{array}$ \\
\hline & $\breve{~}$ & 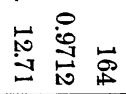 & $\begin{array}{l}\frac{1}{\infty} \\
\text { 咞 }\end{array}$ \\
\hline & 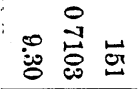 & 농 & $\begin{array}{l}\text { Nै } \\
\text { क्स }\end{array}$ \\
\hline & 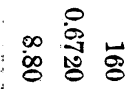 & 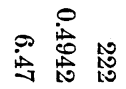 & $\begin{array}{l}\mathscr{8} \\
\text { 雬 }\end{array}$ \\
\hline & 㟧宫官 & 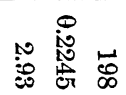 & 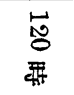 \\
\hline $\begin{array}{l}\text { 九 } \\
\equiv\end{array}$ & 号 & 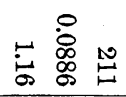 & $\begin{array}{l}\text { 茞 } \\
\text { 栗 }\end{array}$ \\
\hline & 1 & 1 & \begin{tabular}{l}
$\infty$ \\
$\infty$ \\
\multirow{2}{*}{}
\end{tabular} \\
\hline & $\begin{array}{ll}0 & 0 \\
0 & 0 \\
\infty & 0 \\
\infty & 0 \\
\infty & 0\end{array}$ & 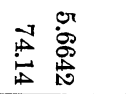 & 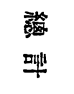 \\
\hline & & & 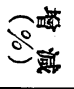 \\
\hline
\end{tabular}

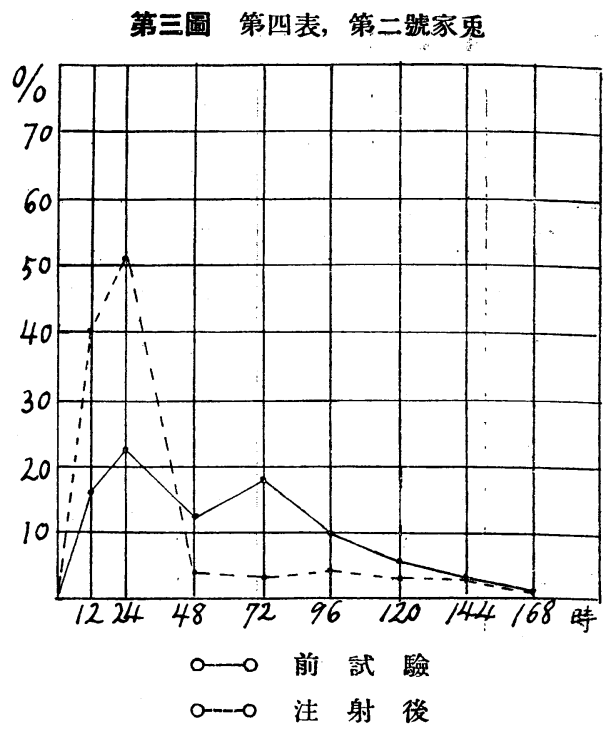

排腦 尿 前

泄垂 排 節

堆 䱏 泄

驾䇎著

來荣意 妊

不機 示婦

云熊适 录

八進

政

扒子興量總量例

䛇宮度射文於

熹癌尿於テ宁

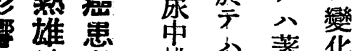

性惹排著蓄變

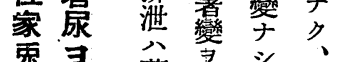

兔录萆訽第

中得琞衴第

患尿知

者中りン

沃多堡 ザ 第

沓擄 共

脽萢感共

得熟次投

亦二與

ルル同沃

度儿潗王第

排ぷ 方例

泄 亏

プモ ジ度

及 $九$ 方的

知 量 


\begin{tabular}{|c|c|c|c|c|c|c|c|c|c|}
\hline & & & \multicolumn{2}{|r|}{ 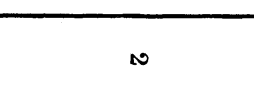 } & 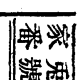 & \\
\hline 㝘 & 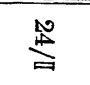 & 馹 & 萿 & 萡 & 等 & $\stackrel{5}{5}$ & 跣 & 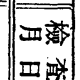 & \\
\hline 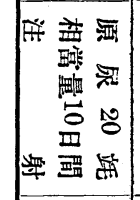 & 要 & 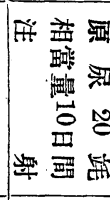 & 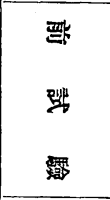 & 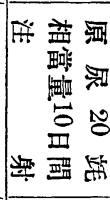 & 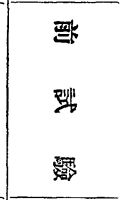 & 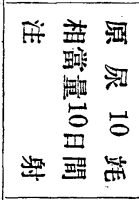 & 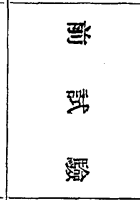 & & \\
\hline 农 & 篔 & 范 & 爵 & 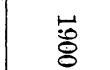 & 落 & 岁 & 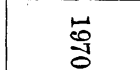 & 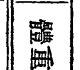 & \\
\hline & & & & & 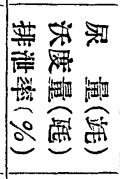 & 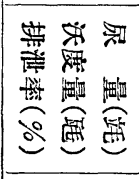 & 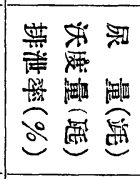 & & \\
\hline & & 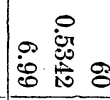 & 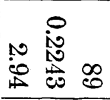 & 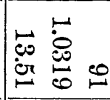 & 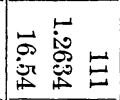 & 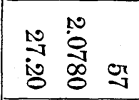 & 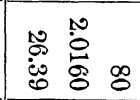 & 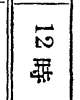 & \\
\hline & 59 & 密总 & 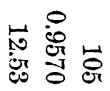 & & 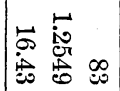 & 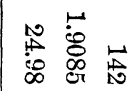 & 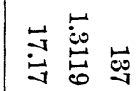 & 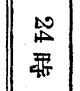 & \\
\hline & 8 & & $\infty$ & 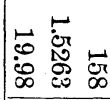 & 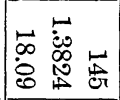 & 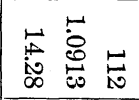 & 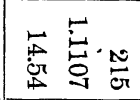 & 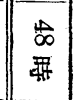 & \\
\hline & 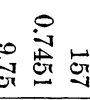 & 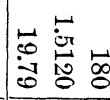 & & 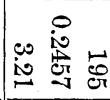 & 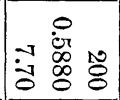 & 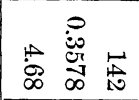 & 总兽 & \begin{tabular}{|l|}
$\overrightarrow{0}$ \\
0 \\
严
\end{tabular} & \\
\hline- & 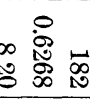 & 90 & 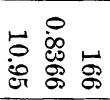 & 焉 & 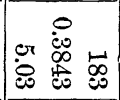 & 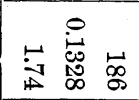 & 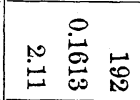 & $\begin{array}{l}8 \\
8 \\
3\end{array}$ & \\
\hline & 50 & & 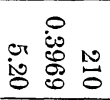 & 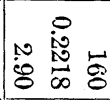 & 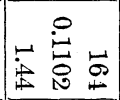 & 范总总 & 尊 & 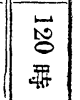 & \\
\hline & 䓢 & 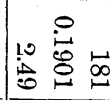 & 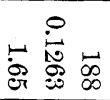 & 昰 鸟 & 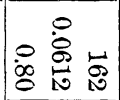 & 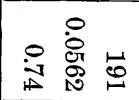 & 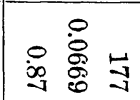 & 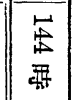 & \\
\hline 总商 & 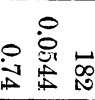 & 离 & 产营 & 1 & 1 & 1 & 1 & 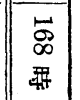 & \\
\hline 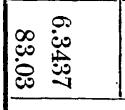 & 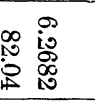 & 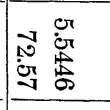 & 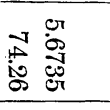 & 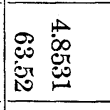 & 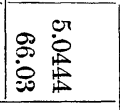 & 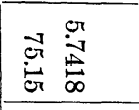 & 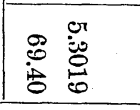 & 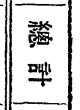 & \\
\hline & & & & & & & & 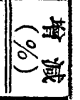 & \\
\hline
\end{tabular}




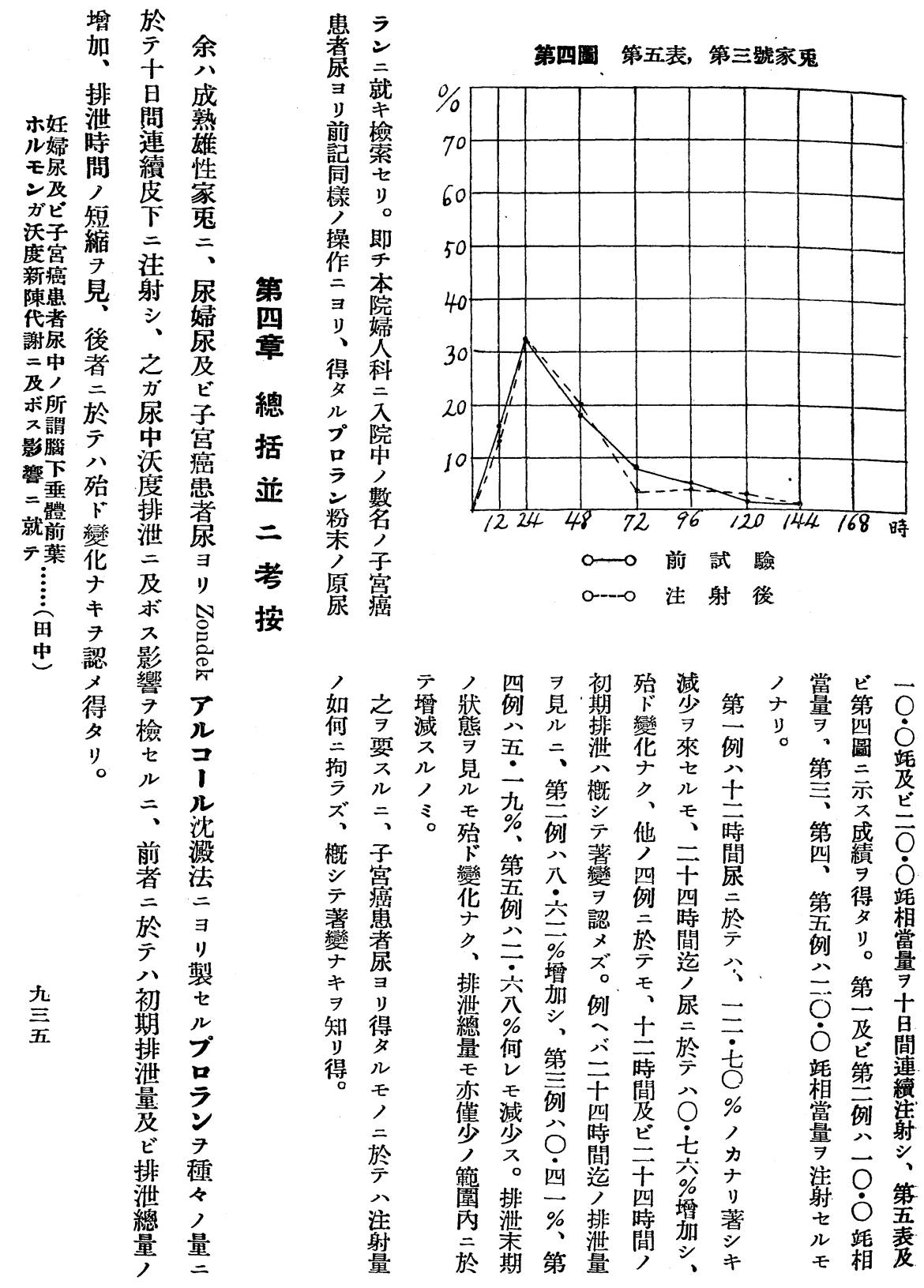




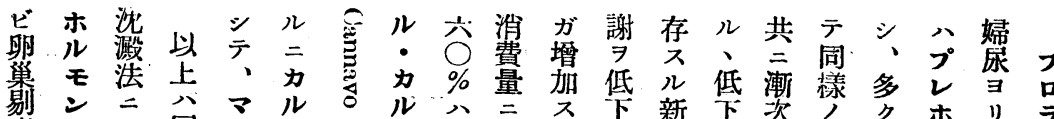

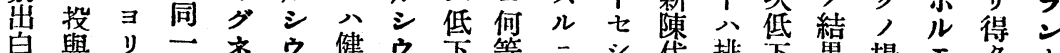

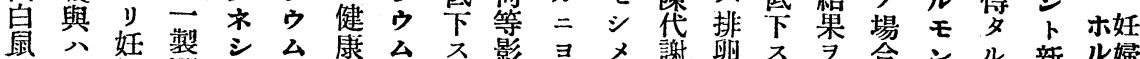

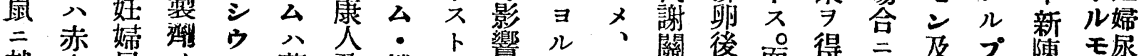

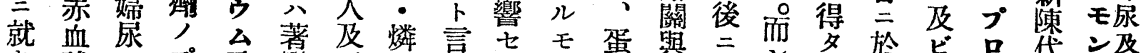

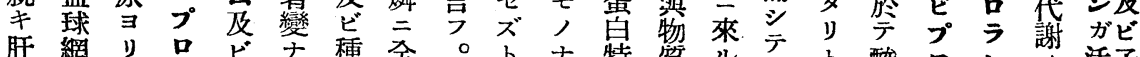

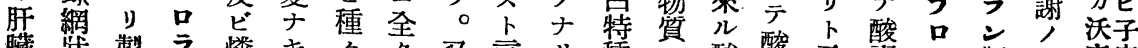

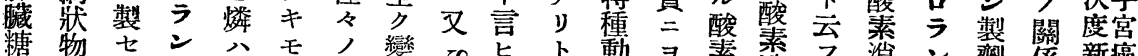

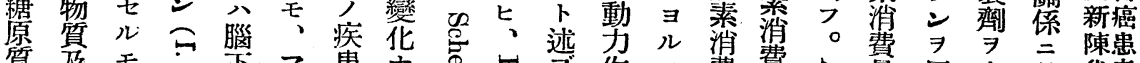

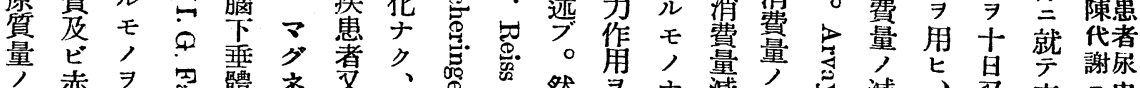

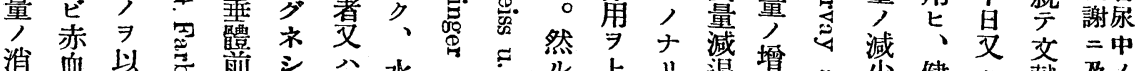
消血求

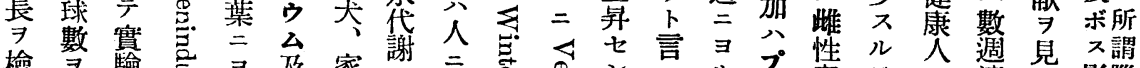

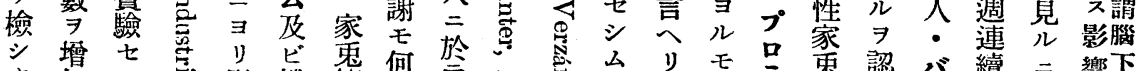

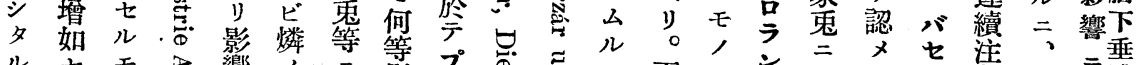

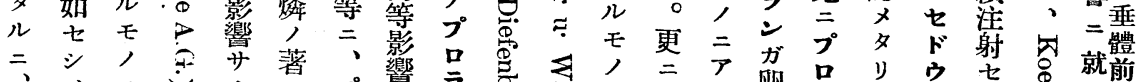

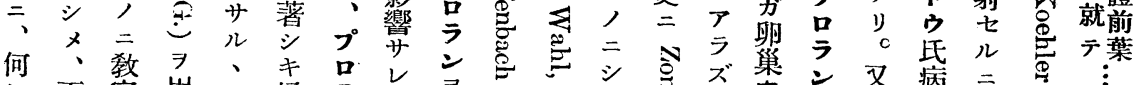

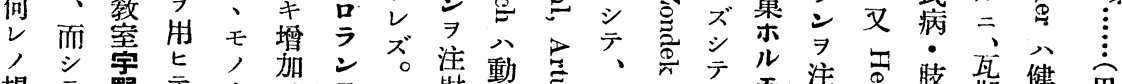
場 シ 宇 合

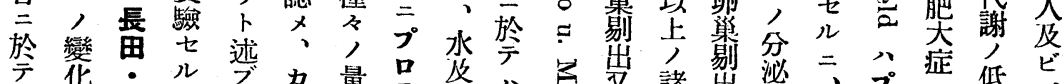
モ化草モ

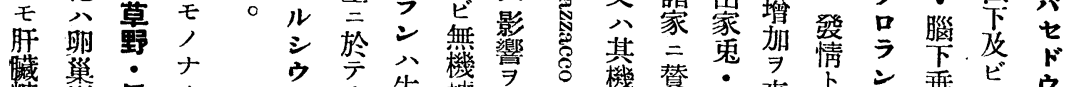

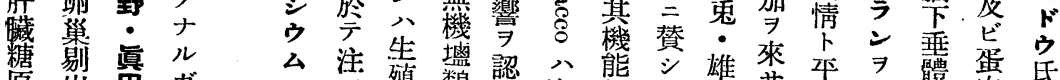

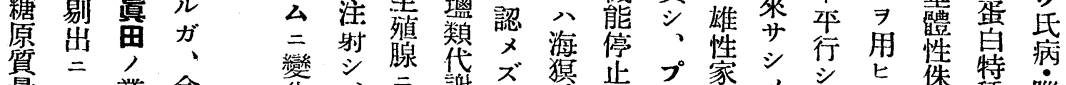

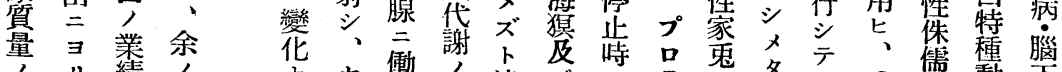

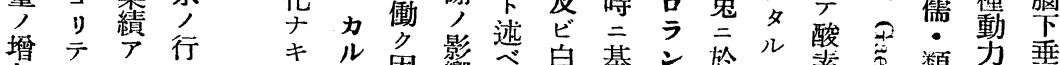
加影

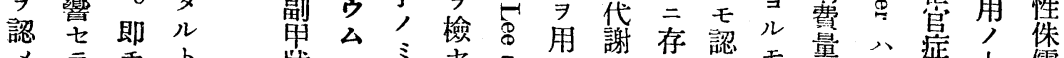

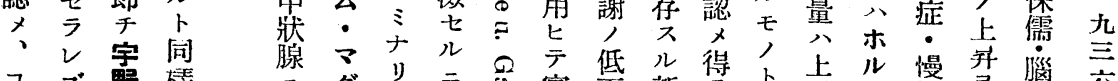

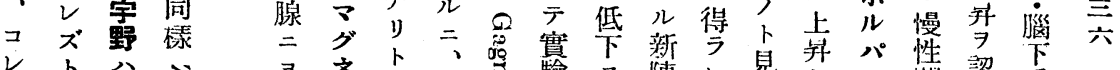

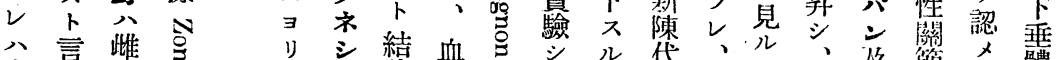

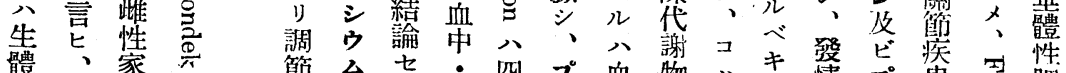
离長兔 ア

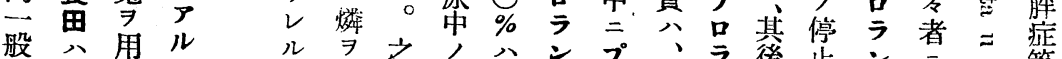

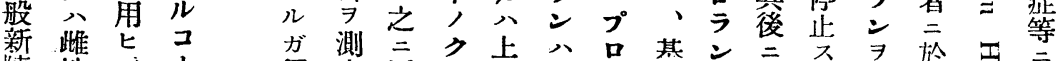

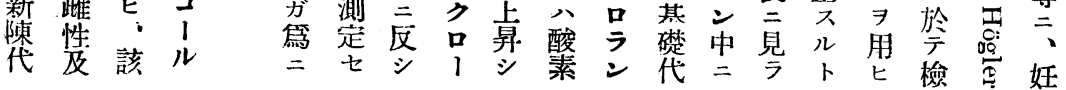




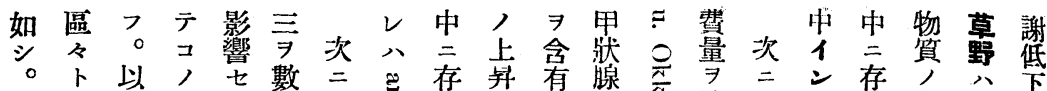

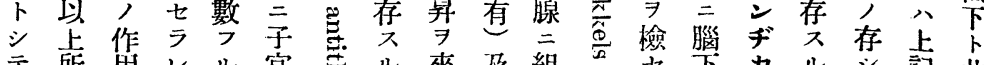

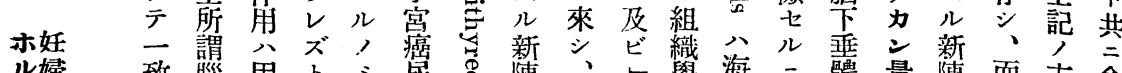

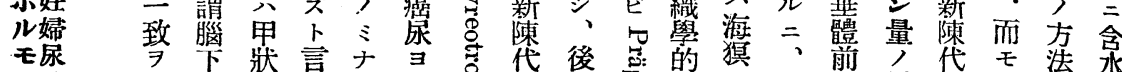

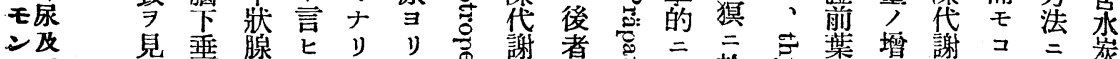

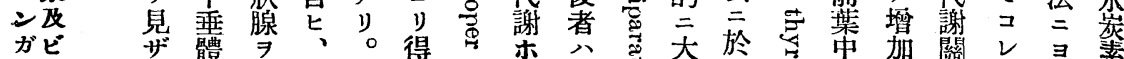
沃子儿前 剔 草 即多却年

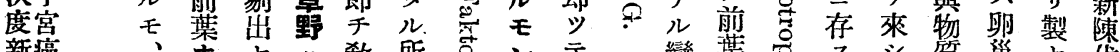

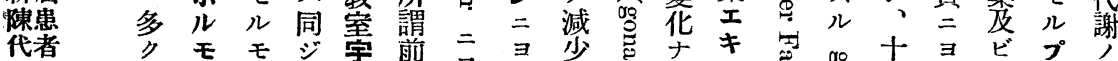

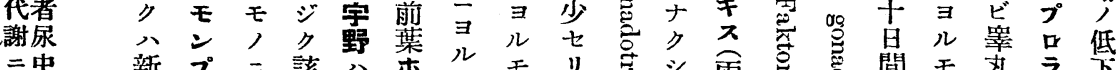
二中 新 プ = 該

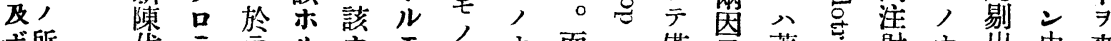

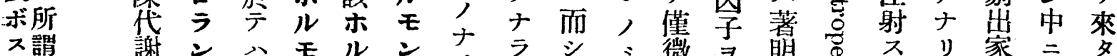

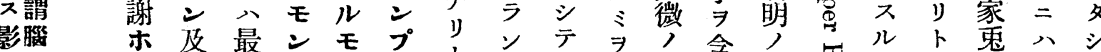

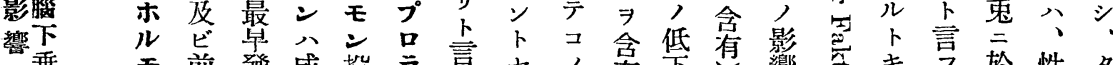

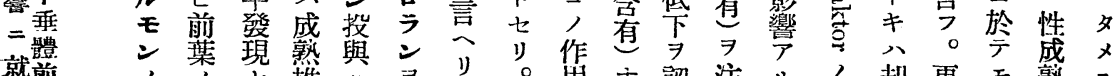

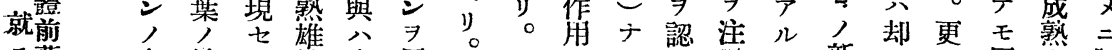
テ葉 存性 ズ性赤用然公ル×射三新 シ三同㷊肝

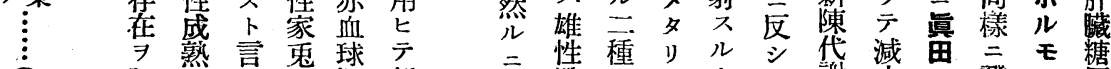
畐 認热言兔球 新 二 性種 リ

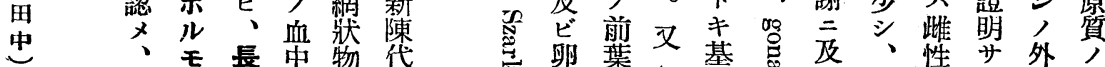

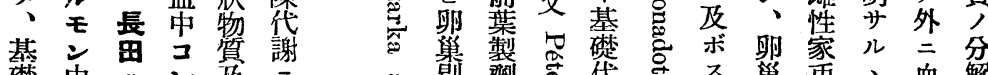

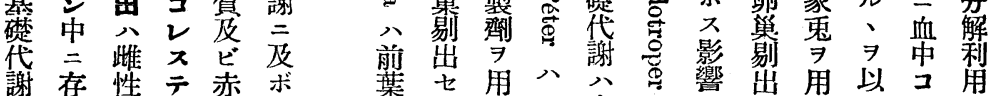
$\exists$ ス显り血 $、$ エ

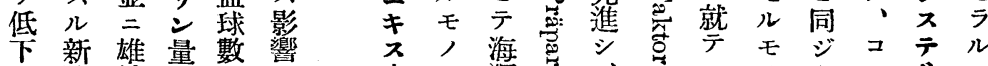

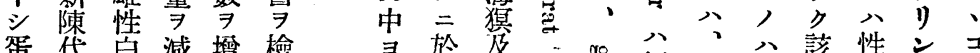

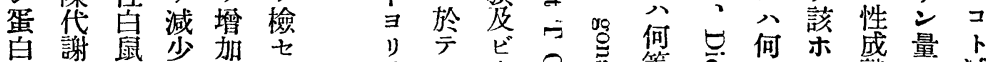

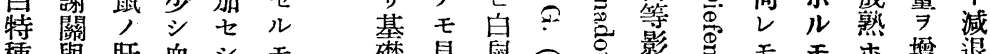

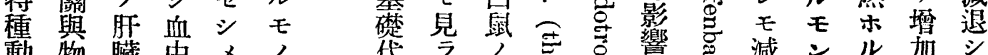

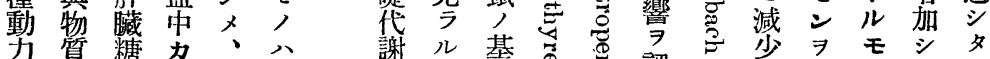

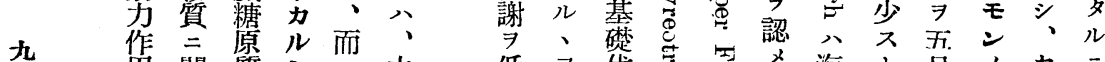

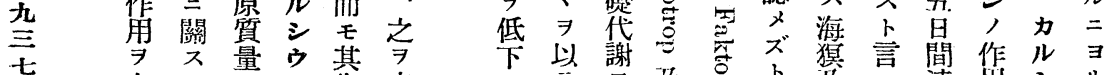

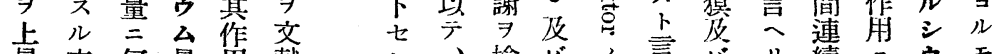

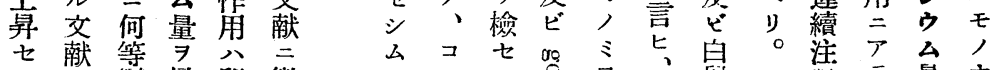

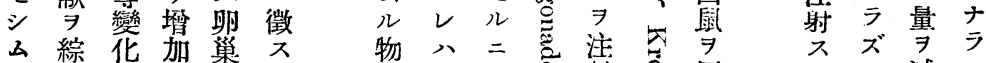

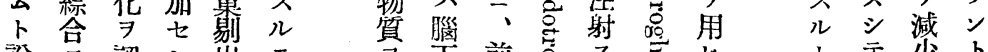

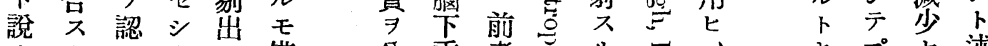
クルメムム

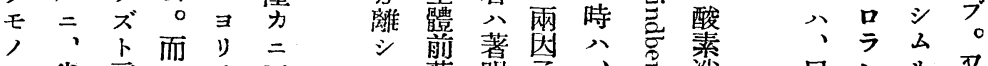

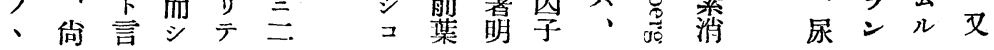




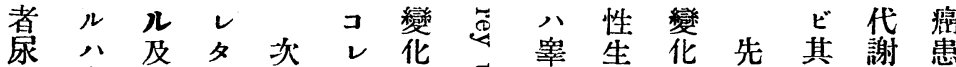

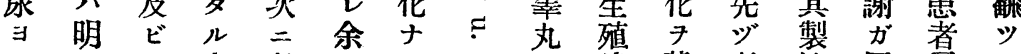

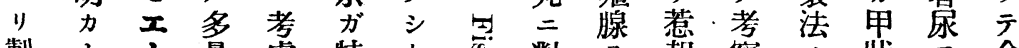

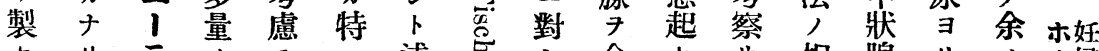

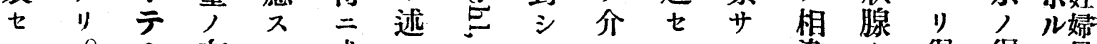

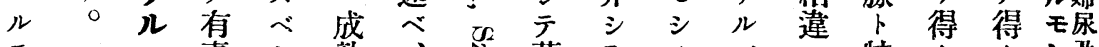

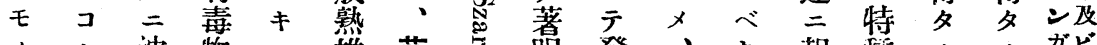

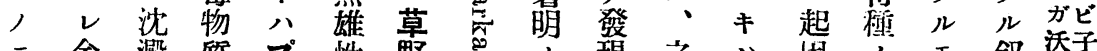

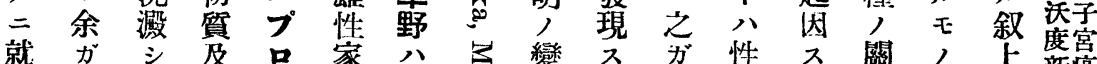
就吕 シ 及 數家八占變

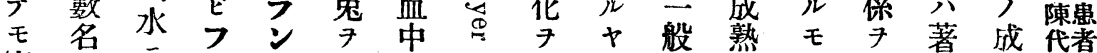
賽分才中選力 與否新禾, 有變績謝泉 驗 弤 可

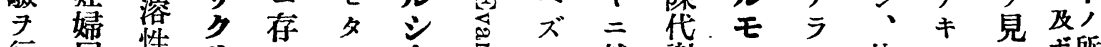
行尿性り ス

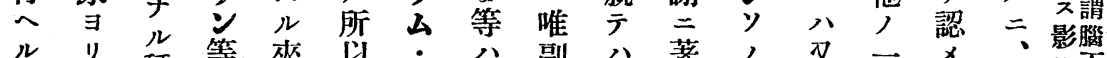

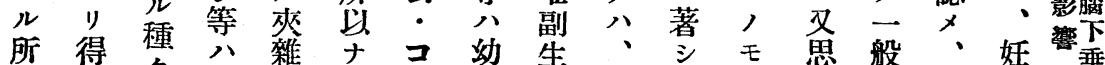

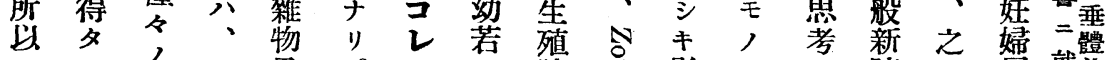

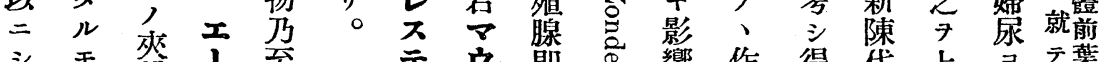

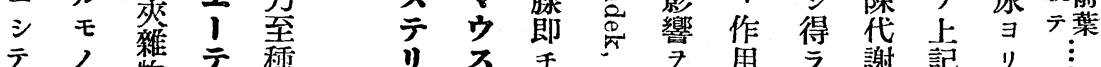

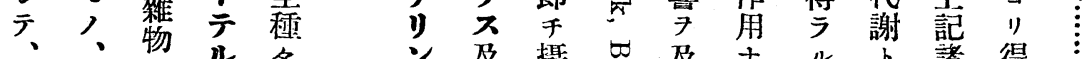
後及心洗, 年量

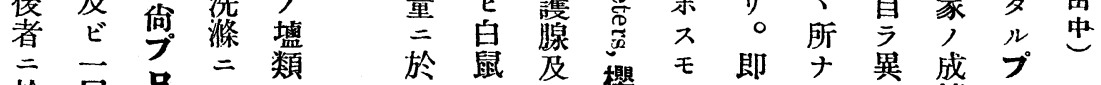

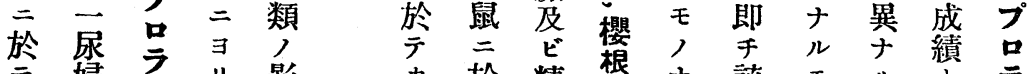

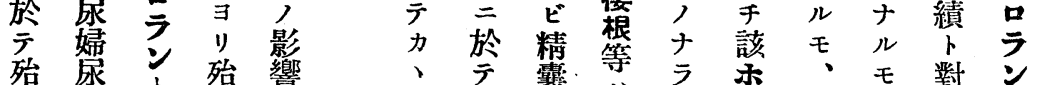

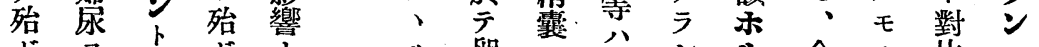

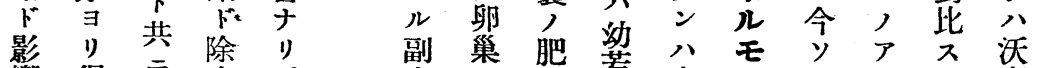

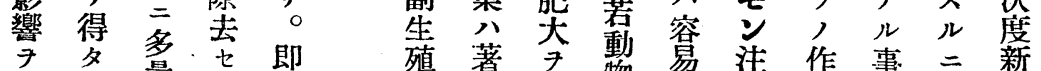

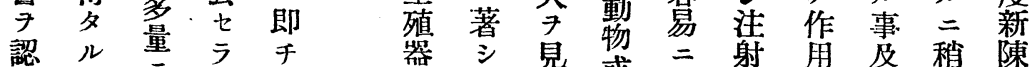
× ザノ 存タ婦大酸, 成考幼現實一謝

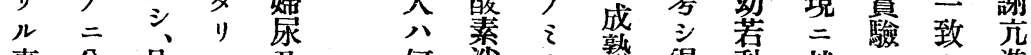

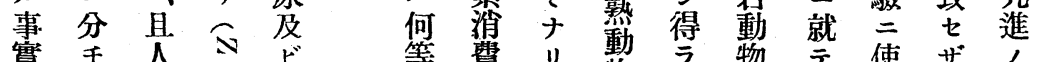
實于人佂

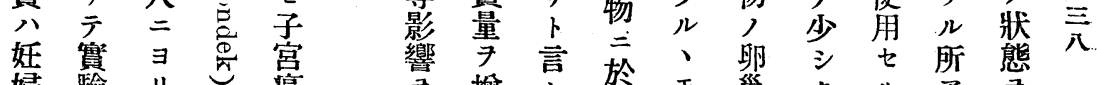

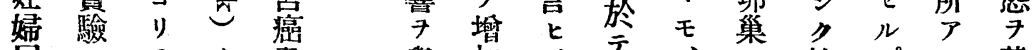

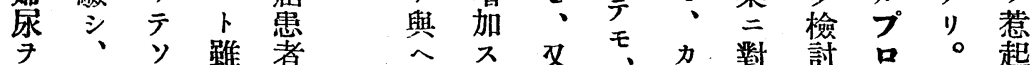

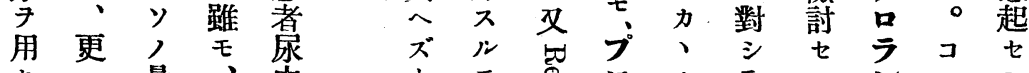
七三量、中 中

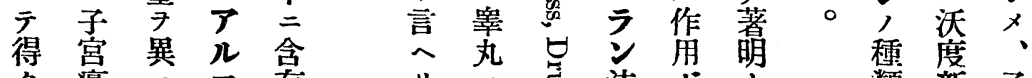

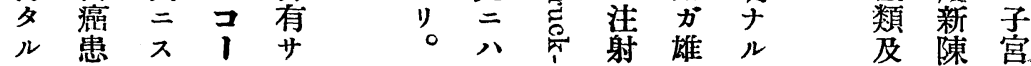




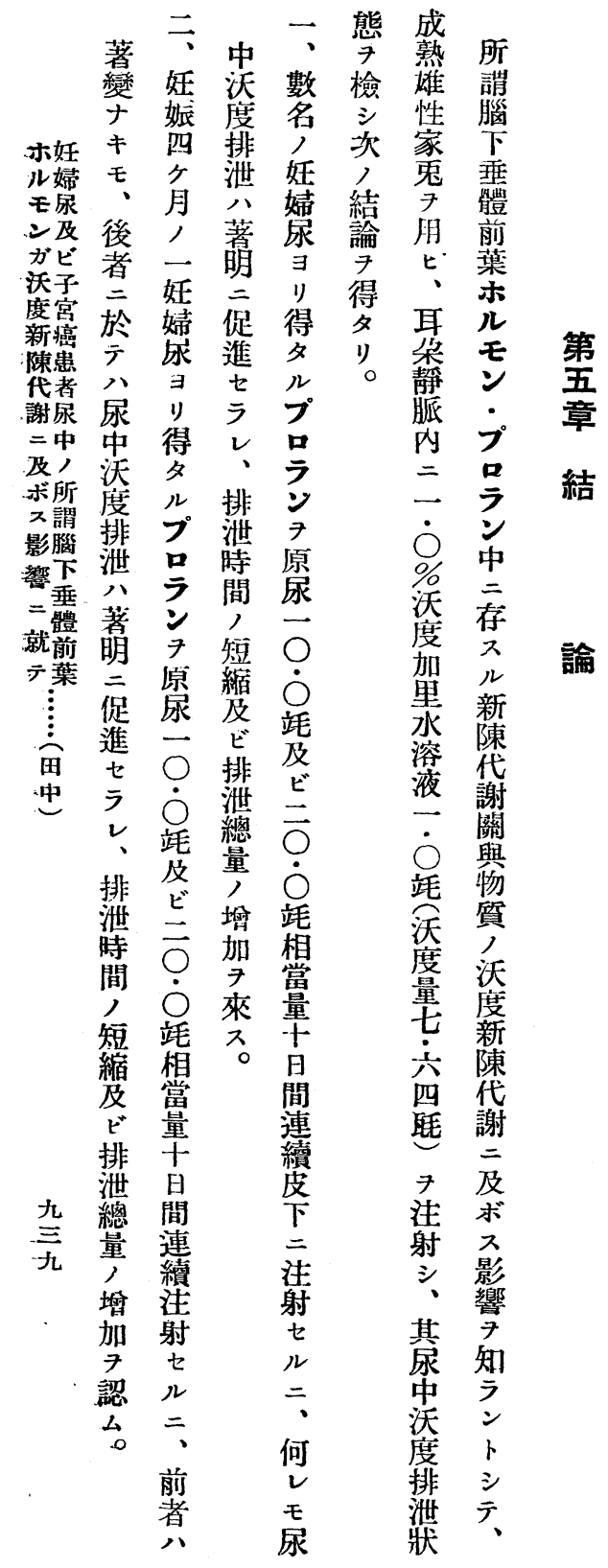

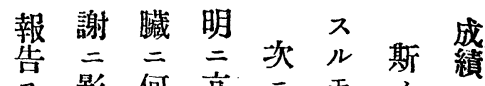

入影何克二モ, 公

儿響 等 淮 然, 如是

所 カ セラナク等

ア與ノシバル詮莝

ルフ影 $メ$ 草 7 稚

べ響・野 斷來物

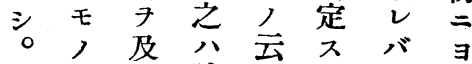

ニボ脾フル、う

ア シ瀻如二本ザ

ラ、剔ク憚實 ル

ザソ出脾ラ驗事

ル, 二瓷 ズ

十結 $\exists \exists \circ$ 於實

二果”介證

就沃甲 シ 證 ス

テ度狀 $\bar{シ} ル$

八代腺發得王

、謝機現多,

更了能 ス皇

追淮淮モ度。

究子

檢、見招ナ陳

討 ル來り帒

ス $=$ t + 謝

ギラル否秃

興ザ $コ$ 進

味ル ル 就 プ

問或ナ只 号

題分”余品

畐報最

テ接告 $=$ 存

、盟 $七$ 脾

之狀ル贜歲

二腺毛剔新

關 $=$ 、出陳

シ 作 プ 帒

テ角品沃謝

八シ $シ$ 度關

第 $\bar{y}$ 新 與

茲注陳物

篇 三射代 質

二沃公謝 二

於度及寻击 


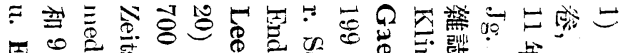

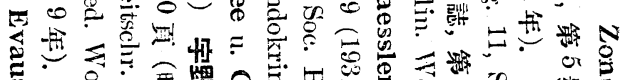

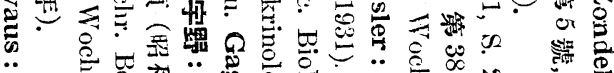

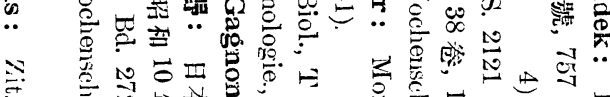

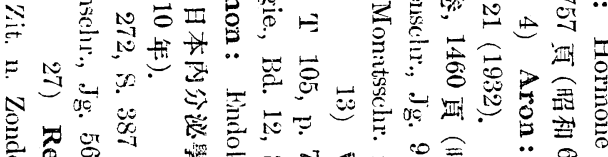

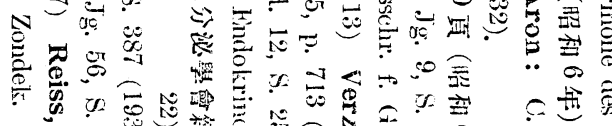

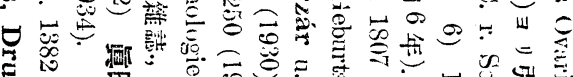

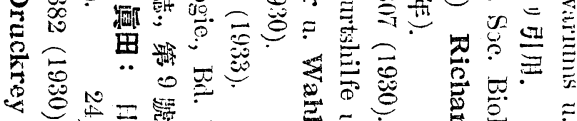

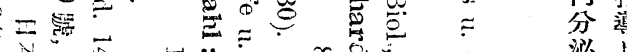

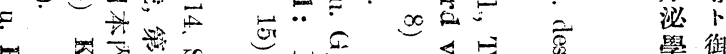

羿密學御

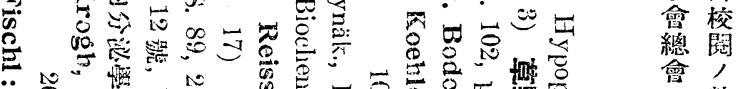

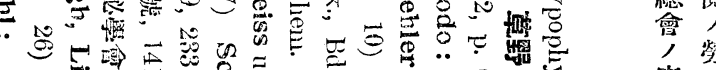

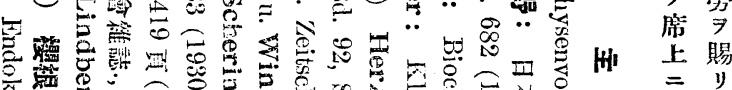

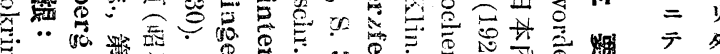

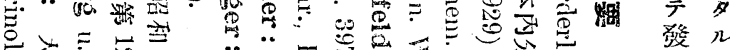

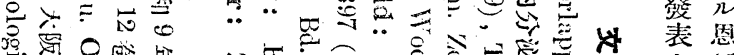

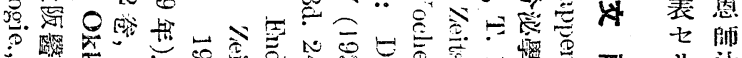

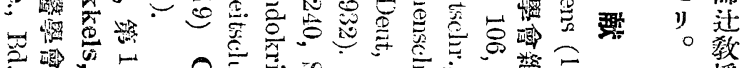

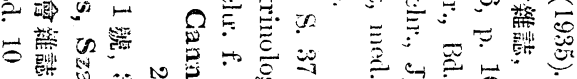

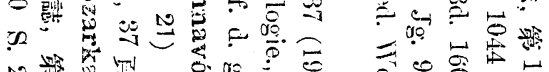

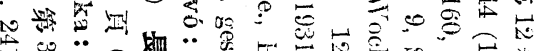

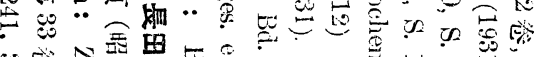

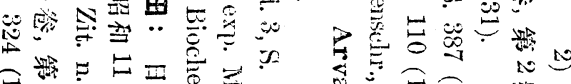

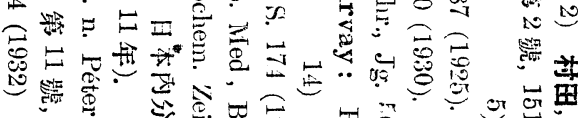

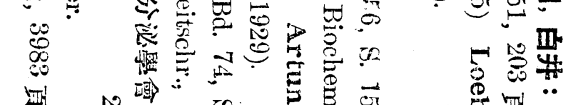

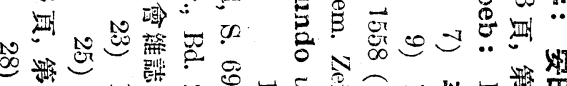

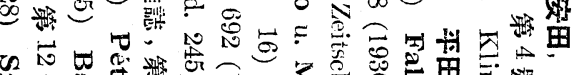

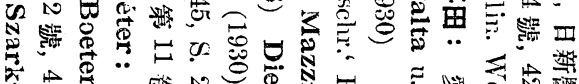

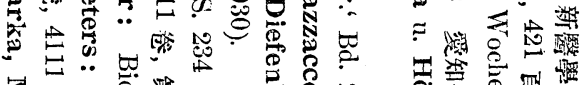

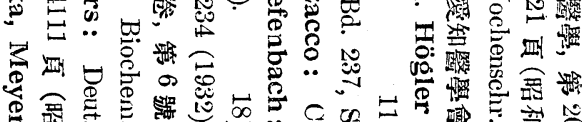

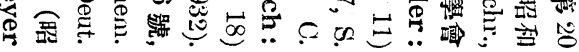


8) Ovarienexstirpation verursacht geringe Zunahme desselben.

(Autoreferat)

\section{Über den Einfluss des aus dem Harn von Schwangeren und von Kranken mit Uteruskrebs hergestellten sogenannten Hypophysenvorderlappenhormons auf die Jodausscheidung im Harne. \\ I. Mitteilung : Versuch am erwachsenen männlichen Kaninchen.}

\section{Von}

Dr. I. Tanaka.

(Aus der I. Med. Klinik der Kaiserl. Univers. zu Kyote in Japan. Direktor: Prof. Dr. K. Tsuji).

Um sich über den Einfluss des sog. Hypophysenvorderlappenhormons, d. h. des Prolans, zum Jodstoffwechsel Klarheit zu verschaffen, injizierte der Verfasser erwachsenen männlichen Kaninchen $1 \mathrm{ccm}$ $1 \%$ iger Jodkaliumlösung intravenös und untersuchte nach der modifizierten Fellenbergschen Bestimmungsmethode den zeitlichen Verlauf der Jodausscheidung im Harne. Das Prolan wurde nach der ursprünglichen Zondekschen Alkoholfällungmethode aus dem Harn von Schwangeren und von Kranken mit Uteruskrebs hergestellt.

Die Resultate sind die folgenden:

1) Durch die täglich einmal 10 Tage lang durchgeführte Injektion verschiedener Dosen des aus dem Harne einiger Schwangeren hergestellten Prolans wurde die Jodausscheidung im allgemeinen so beschleunigt, dass die Ausscheidung schnell beendet und die ausgeschiedene gesamte Jodmenge grösser als die von der Injektion war.

2) Bei der 10 Tage lang fortgesetzten Injektion verschiedener Dosen des aus dem Harn von Kranken mit Uteruskrebs hergestellten Prolans waren sowohl die Ausscheidungskurve als auch die Ausscheidungsmenge fast wie vor der Injektion.

3) Aus den obigen Ergebnissen schliesst der Verfasser, dass der Harn von Schwangeren eine den Jodstoffwechsel steigende Substanz 
enthält, der Harn von Kranken mit Unteruskrebs dagegen nicht.

(Autoreferat)

\title{
Über den Einfluss des aus dem Harn von Schwangeren und von Kranken mit Uteruskrebs hergestellten sogenannten Hypophysenvorderlappenhormons auf die Jodausscheidung im Harne. II. Mitteilung: Versuch am splenektomierten sowie am thyreoidektomierten erwachsenen männlichen Kaninchen.
}

\author{
Von \\ Dr. I. Tanaka.
}

(Aus der I. Med. Klinik der Kaiserl. Univers. zu Kyoto in Japan. Direktor : Prof. Dr. K. Tsuji).

In dieser Mitteilung untersuchte der Verfasser am splenektomierten sowie am thyreoidektomierten erwachsenen männlichen Kaninchen die Veränderung der Jodausscheidung, zu der es durch wiederholte Injektion des sog. Hypophysenvorderlappenhormons, d. h. des Prolans, kommit.

Die Resultate sind die folgenden :

1) Bei den splenektomierten Kaninchen wird durch fortgesetzte Injektion des Prolans die Jodausscheidung auffallend schneller und schneller vollendet und weiter die ausgeschiedene Gesamtjodmenge deutlich grösser als bei den Kaninchen mit einfacher Milzexstirpation.

2) Bei den thyreoidektomierten Kaninchen kommt es durch fortgesetzte Injektion des Prolans zu der obenberichteten Wirkung nicht.

3) Den obigen Resultaten nach wirkt die im Schwangerenharn enthaltene Substanz auf den Jodstoffwechsel über die Schilddrüse hinweg und völlig unabhängig von der Milz. Das bedeutet, dass die wirksame Substanz mit dem sog. thyreotropen Hormon fast 